\title{
Synthesis and Mechanism of Formation of Novel NHC-NAC Bis-Carbene Complexes of Gold(I)
}

\author{
Luciano Canovese, ${ }^{*}{ }^{\dagger}$ Fabiano Visentin, ${ }^{\dagger}$ Carlo Levi ${ }^{\dagger}$ and Valerio Bertolasi ${ }^{\sharp}$ \\ ${ }^{\dagger}$ Dipartimento di Chimica, Università Ca’ Foscari, Venice, Italy, and ${ }^{\star}$ Dipartimento di Chimica and Centro di \\ Strutturistica Diffrattometrica Università di Ferrara, Ferrara, Italy
}

Received November 10, 2010

\begin{abstract}
Novel $[\mathrm{Au}(\mathrm{NHC})(\mathrm{DIC})] \mathrm{BF}_{4}$ complexes $(\mathrm{NHC}=\mathrm{SIMes}$, IMes, SIPr, IPr; DIC = 2,6-dimethylphenyl isocyanide) were synthesized and characterized. These substrates react with secondary amines at room temperature under mild experimental conditions to give new bis-carbene NHC-NAC derivatives. The reaction of formation of the latter complexes with piperidine, morpholine, and diethylamine was studied by NMR and UV-vis spectrometry, and a mechanism involving a concomitant attack of the amine at the metal center and at the coordinated isocyanide was proposed on the basis of a detailed kinetic study. The mechanistic network was completely resolved by means of an independent determination of the equilibrium constant of formation of the adduct [ $\mathrm{Au}(\mathrm{NHC})$ (DIC)(amine) $]^{+}, K_{\text {eq }}$, calculated from the absorbance vs amine concentration data obtained from direct spectrophotometric titration of the starting complex $[\mathrm{Au}(\mathrm{NHC})(\mathrm{DIC})]^{+}$with the amine. The $\left[\mathrm{Au}(\mathrm{NHC})\left\{\mathrm{C}(\mathrm{NHAr})\left(\mathrm{NC}_{5} \mathrm{H}_{10}\right)\right\}\right] \mathrm{BF}_{4}$ bis-carbene complexes obtained by attack of piperidine at the $[\mathrm{Au}(\mathrm{NHC})(\mathrm{DIC})]$ derivatives were isolated and fully characterized. The solid-state structures of the new complexes $[\mathrm{Au}(\mathrm{IMes})(\mathrm{DIC})] \mathrm{BF}_{4}$ and $\left[\mathrm{Au}(\mathrm{IMes})\left\{\mathrm{C}(\mathrm{NHAr})\left(\mathrm{NC}_{5} \mathrm{H}_{10}\right)\right\}\right] \mathrm{BF}_{4}$ were resolved and reported.
\end{abstract}

\section{Introduction}

Among all the stimulating aspects of modern organometallic chemistry our attention was attracted by the interesting reactivity of carbene derivatives of gold(I). As a matter of fact, since the synthesis of the first stable NHC derivatives

(1) (a) Arduengo, A. J.; Harllow, R. L.; Kline, M. J. J. Am. Chem. Soc. 1991, 113, 361-363. (b) Arduengo, A. J.; Dias, H. V. R.; Calabrese, J. C.; Davidson, F. J. Am. Chem. Soc. 1992, 114, 5530-5534. (c) Arduengo, A. J.; Dias, H. V. R.; Calabrese, J. C.; Davidson, F. J. Am. Chem. Soc. 1992, $114,9724-9725$

(2) (a) Enders, D.; Niemlier, O.; Henseler, A. Chem. Rev. 2007, 107, 5606-5655. (b) Arndt, S.; Schrock, R. R.; Mueller, P. Organometallics 2007, 26, 1279-1290. (c) Schrock, R. R. Adv. Synth. Catal. 2007, $349(1+2), 25$. (d) Schrock, R. R. Adv. Synth. Catal. 2007, $349(1+2), 41-53$. (e) Schrock, R. R.; Czekelius, C. Adv. Synth. Catal. 2007,349 (1+2), 55-77. (f) Grubbs, R. H. Adv. Synth. Catal. 2007, 349 (1+2), 23-24. (g) Grubbs, R. H. Adv. Synth. Catal. 2007, $349(1+2), 34-40$. (h) Mohapatra, D. K.; Ramesh, D. K.; Giardello, M. A.; Chorghade, M. S.; Gurjar, M. K; Grubbs, R. H. Tetrahedron Lett. 2007, 48, 2621-2625. (i) Berlin, J. M.; Campbell, K.; Ritter, T.; Funk, T. W.; Chlenov, A.; Grubbs, R. H. Org. Lett. 2007, 9, 3175-3177. (j) Glorius, F. In N-Heterocyclic Carbenes in Transition Metal Catalysis; Springer: New York, 2006. (k) Nolan, P. S. In $\mathrm{N}$ Heterocyclic Carbenes in Synthesis; Wiley-VCH: Weinheim, Germany, 2006. (1) Prokopchuck, E. M.; Puddhephatt, R. J. Organometallics 2003, 22, 563-566. (m) Herrmann, W. A. Angew. Chem., Int. Ed. 2002, 41, 12901309.

(3) (a) Trnka, T. M; Grubbs, R. H. Acc. Chem. Res. 2001, 34, 18-29. (b) Weskamp, T.; Bohm, V. P.; Hermann, W. A. J. Organomet. Chem. 2000, 600, 12-22. (c) Jafapour, L; Nolan, S. P. Adv. Organomet. Chem. 2000, 46, $181-222$.

(4) (a) Michrowska, A.; Bujok, R.; Harutyunyan, S.; Sashuk, V.; Dolgonos, G.; Grela, K. J. Am. Chem. Soc. 2004, 126, 9318-9325. (b) Van, V. J. J.; Campbell, J. E.; Giudici, R. E.; Hoveyda, A. H. J. Am. Chem. Soc. 2005, 127, 6877-6882. (c) Funk, T. W.; Berlin, J. M.; Grubbs, R. H. J. Am. Chem. Soc. 2006, 128, 1840-1846. by Arduengo and co-workers, ${ }^{1}$ carbene complexes of the transition metal have acquired a paramount importance in the field of metal catalyzed reactions ${ }^{2}$ and the NHC carbene derivatives of palladium, ${ }^{21,3}$ ruthenium, ${ }^{4}$ nickel ${ }^{5}$ and platinum ${ }^{6}$ were often employed as useful substitutes of phosphine or phosphite complexes. Conversely, the carbene complexes of gold(I) did not initially received much attention, but at present they undergo a remarkable development thanks to their versatility as catalysts, ${ }^{7}$ luminescent devices, ${ }^{8}$ and potential drugs. ${ }^{9}$

Since the seventies, it was known that amines attack isocyanides coordinated to a transition metal to give the corresponding NAC carbene derivatives ${ }^{10}$ (NAC $=$ nitrogen acyclic carbene) and such a protocol has been used by Vicente, Espinet and co-workers in the synthesis of gold(I) NAC carbene derivatives. ${ }^{11}$ On the basis of the described outcomes, we have programmed the synthesis of new mixed bis-carbene NHC, NAC derivatives, which might be employed in the olefin diboronation analogously to their homoleptic $\left[\mathrm{Au}(\mathrm{NHC})_{2}\right]^{+}$complexes $^{12}$ or as active antibacterial agents. ${ }^{13}$ Thus, we have first synthesized the complexes $[\mathrm{Au}(\mathrm{NHC})(\mathrm{DIC})] \mathrm{BF}_{4}(\mathrm{NHC}=$ SIMes, IMEs, SIPr, IPr;

(5) (a) Blakey, S,B.; McMillan, D. W. C. J. Am. Chem. Soc. 2003, 125, 6046-6047. (b) Omar-Amrani, R.; Thomas, A.; Brenner, E.; Scnheider, R.; Fort, Y. Org. Lett. 2003, 5, 2311-2314. (c) Kuhl, S.; Fort, Y.; Schneider, R. J. Organomet. Chem. 2005, 690, 6169-6177.

(6) (a) Sprengers, J. W.; Mars, M. J.; Duin, M. A.; Cavell, K. J.; Elsevier, C. J. J. Organomet. Chem. 2003, 679, 149-152. (b) Mark, I. E.; Sterin, S.; Buisine, O.; Berthon, G.; Michaud, G.; Tinant, B.; Declerq, J.-P. Adv. Synth. Catal. 2004, 346, 1429-1434. (c) Berthon-Gelloz, G.; Buisine, O.; Briere, J.-F.; Michaud, G.; Sterin, S.; Mignani, G.; Declerq, J.-P.; Chapon, D.; Mark, I. E. J. Organomet. Chem. 2005, 690, 6156-6168. 
$\mathrm{DIC}=2,6$-dimethylphenyl isocyanide) and hence, by means of nucleophilic attack at the isocyanide moiety with secondary amines with different basicities and steric demands, we have obtained the species $[\mathrm{Au}(\mathrm{NHC})(\mathrm{NAC})] \mathrm{BF}_{4}$, which represented our synthetic target.

The complete synthetic strategy and a detailed mechanistic study of the amination reaction and the influence of steric and electronic parameters on the reaction will be described in the present paper.

\section{Results and Discussion}

Synthesis of Complexes of the Type $[\mathrm{Au}(\mathrm{NHC})(\mathrm{DIC})] \mathrm{BF}_{4}$. We have synthesized novel complexes of the type [Au(NHC)(DIC) $] \mathrm{BF}_{4}$ by reacting the carbene derivatives $[\mathrm{Au}(\mathrm{NHC})-$ $\mathrm{Cl}$, obtained according to published procedures, ${ }^{2 \mathrm{~m}, 14}$ with the isocyanide DIC in the presence of a stoichiometric amount of $\mathrm{AgBF}_{4}$ in $\mathrm{CH}_{2} \mathrm{Cl}_{2}$ at room temperature (Scheme 1).

The formation of the complexes $[\mathrm{Au}(\mathrm{NHC})(\mathrm{DIC})] \mathrm{BF}_{4}$ was confirmed by means of ${ }^{1} \mathrm{H}$ and ${ }^{13} \mathrm{C}$ NMR spectra and, in the case of the complex $[\mathrm{Au}(\mathrm{IMes})(\mathrm{DIC})] \mathrm{BF}_{4}$, by a crystal structure determination (vide infra). In particular, the

(7) (a) Lin, J. C. Y.; Huang, R. T. W.; Lee, C. S.; Bhattacharyya, A.; Hwang, W. S.; Lin, I. J. B. Chem. Rev. 2009, 109, 3561-3598. (b) Raubenheimer, H. G.; Cronje, S. Chem. Soc. Rev. 2008, 37, 1998-2011. (c) De Frémont, P.; Scott, N. M.; Stevens, E. D.; Nolan, S. P. Organometallics 2005, 24, 2411-2418. (d) Gaillard, S.; Bantreil, X.; Slawin, A. M. Z.; Nolan, S. P. Dalton Trans. 2009, 6967-6971. (e) Baker, M. V.; Barnard, P. J.; Brayshaw, S. K.; Hickey, J. L.; Skelton, B. W.; White, A. H. Dalton Trans. 2005, 37-43. (f) Marion, N.; Nolan, S. P. Chem. Soc. Rev. 2008, 37, 17761782. (g) Jothibasu, R.; Huynh, H. V.; Koh, L. L. J. Organomet. Chem. 2008, 693, 374-380. (h) De Frémont, P.; Marion, N.; Nolan, S. P. J. Organomet. Chem. 2009, 694, 551-560. (i) Brown, T. J.; Dickens, M. G.; Widenhoefer, R. A. J. Am. Chem. Soc. 2009, 131, 6350-6351. (j) Chiou, J. Y. Z.; Luo, S. C.; You, W. C.; Bhattacharyya, A.; Vasam, C. S.; Huang, C. H.; Lin, I. J. B. Eur. J. Inorg. Chem. 2009, 1950-1959. (k) Frey, G. D.; Dewhurst, R. D.; Kousar, S.; Donnadieu, B.; Bertrand, G. J. Organomet. Chem. 2008, 693, 1674-1682. (1) Partyka, D. V.; Robilotto, T. J.; Updegraff, J. B.; Zeller, M.; Hunter, A. D.; Gray, T. G. Organometallics 2009, 28, 795-801. (m) Akana, J. A.; Bhattacharyya, K. X.; Müller, P.; Sadighi, J. J. Am. Chem. Soc. 2007, 129, 7736-7737. (n) Li, Z.; Brouwer, C.; He, C. Chem. Rev. 2008, 108, 3293-3265. (o) Marion, M.; Ramón, R. S.; Nolan, S. P. J. Am. Chem. Soc. 2009, 131, 448-449. (p) Zeng, X.; Frey, G. D.; Kousar, S.; Bertrand, G. Chem. Eur. J. 2009, 15, 3056-3060. (q) Zeng, X.; Frey, G. D.; Kinjo, R.; Donnadieu, B.; Bertrand, G. J. Am. Chem. Soc. 2009, 131, 8690-8696. (r) Lavallo, V.; Frey, G. D.; Donnadieu, B.; Soleilhavoup, M.; Bertrand, G. Angew. Chem., Int. Ed. 2008, 47, 5224-5228. (s) Boogaerts, I. I. F.; Nolan, S. P. J. Am. Chem. Soc. 2010, 132, 8858-8859.

(8) Bernard, P. J.; Wedlock, E.; Baker, M. V.; Berners-Price, D.; Joice, A.; Skelton, B. W.; Steer, J. H. Angew. Chem., Int. Ed. 2006, 45, 5966-5970.

(9) Baker, M. V.; Bernard, P. J.; Berners-Price, D.; Brayshaw, S. K.; Hickey, J. L.; Skelton, B. W.; White, A. H. Dalton Trans. 2006, 37083715 .

(10) Bonati, F.; Minghetti, G. Gazz. Chim. Ital. 1973, 103, 373-386.

(11) (a) Bartolomé, C.; Ramiro, Z.; Garcia-Cuadrado, D.; PérezGalan, P.; Raducan, M.; Bour, C.; Echavarren, A. M.; Espinet, P. Organometallics 2010, 29, 951-956. (b) Bartolomé, C.; Garcia-Cuadrado, D.; Ramiro, Z.; Espinet, P. Organometallics 2010, 29, 3589-3592. (c) Bartolomé, C.; Garcia-Cuadrado, D.; Ramiro, Z.; Espinet, P. Inorg. Chem. 2010, 49, 9758-9764. (d) Vicente, J.; Chicote, M. T.; Abrisqueta, M. D.; Jones, P. G. Organometallics 1997, 16, 5628-5636. (e) Vicente, J.; Chicote, M. T.; Abrisqueta, M. D.; Ramirez de Arellano, M. C.; Jones, P. G.; Humphrey, M. G.; Cifuentes, M. P.; Samoc, M.; Luther-Davies, B. Organometallics 2000, 19, 2968-2974. (f) Vicente, J.; Chicote, M. T.; Abrisqueta, M. D.; Alvarez-Falcon, M. M.; Ramirez de Arellano, M. C.; Jones, P. G. Organometallics 2003, 22, 4327-4333.

(12) Corberán, R.; Ramirez, J.; Poyatos, M.; Peris, E.; Fernández, E. Tetrahedron: Asymmetry 2006, 17, 1759-1762.

(13) Özdemir, I.; Denizci, A.; Öztürk, H. T.; Çetinkaya., B. Appl. Organomet. Chem. 2004, 18, 318-322.

(14) (a) Herrmann, W. A.; Köher, C. Angew. Chem., Int. Ed. Engl. 1997, 36, 2162-2187. (b) Hermann, W. A.; Köher, C.; Gooben, L. J.; Artus, J. R. J. Chem. Eur. J. 1996, 2, 772-780. (c) Garrou, P. E. Chem. Rev. 1985, $85,171-185$.
Scheme 1

$\begin{array}{lcc}\mathrm{R}=\text { 2,4,6-trimethylphenyl } & \text { SIMes } & \text { IMes } \\ \mathrm{R}=\text { 2,6-diisopropylphenyl } & \mathrm{SIPr} & \mathrm{IPr}\end{array}$

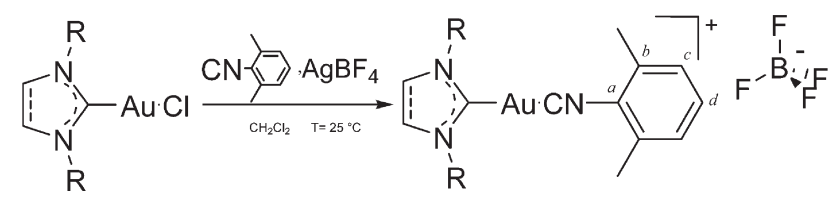

downfield shift of the signal of the aromatic isocyanide proton $\mathrm{H}^{d}$ (with respect to that of the free molecule) and those related to the NHC imidazolium $\mathrm{CH}$ or imidazolinium $\mathrm{CH}_{2}$ protons (with respect to those of the starting chlorocarbene complexes) (see Scheme 1 and Table 1) witness the displacement of chloride ion from the complexes [Au$(\mathrm{NHC}) \mathrm{Cl}$ ] by the neutral isocyanide with a consequent increase in the positive charge on the metal center. No remarkable changes in the chemical shifts of all the other signals were observed.

For the same reason the ${ }^{13} \mathrm{C}$ NMR spectra display the carbene, imidazolium $\mathrm{CH}$, and imidazolinium $\mathrm{CH}_{2}$ carbon signals resonating downfield with respect to those of the corresponding neutral $[\mathrm{Au}(\mathrm{NHC}) \mathrm{Cl}]$ complexes, whereas all the other signals remain almost unchanged (see Table1 and the Experimental Section).

Furthermore, the coordination of the isocyanide DIC is also confirmed by the intense IR band at ca. $2200 \mathrm{~cm}^{-1}$ (the IR band of the uncoordinated DIC is at $\left.2119 \mathrm{~cm}^{-1}\right)$.

Synthesis of Complexes of the Type $\left[\mathrm{Au}(\mathrm{NHC})\left(\mathrm{NAC}^{\mathrm{A}}\right)\right] \mathrm{BF}_{4}$. The reactivity of the DIC derivatives with secondary amines of different steric demand and basicity $\left(\mathrm{NHR}_{2}{ }_{2}=\right.$ piperidine (PIP), morpholine (MOR), diethylamine (DEA)) was verified by means of NMR spectra. Under NMR experimental conditions the reactions were fast and complete and yielded the corresponding bis-carbene derivatives. Scheme 2 displays the typical reaction of insertion of piperidine on the isocyanide fragments of the $[\mathrm{Au}(\mathrm{NHC})(\mathrm{DIC})]^{+}$complexes. Only the complexes derived from insertion of piperidine were isolated by addition of a diethyl ether/hexane mixture to the $\mathrm{CH}_{2} \mathrm{Cl}_{2}$ mother solution and fully characterized (see Experimental Section).

The ${ }^{1} \mathrm{H}$ NMR spectra of the ensuing complexes [Au(NHC)(NAC) $] \mathrm{BF}_{4}$ are characterized by the appearance of the signals ascribable to the protons of the coordinated piperidine. Remarkably, the $\mathrm{H}^{2}$ pip and $\mathrm{H}^{6}$ pip protons (see Scheme 2 and Table 1) resonate at different chemical shifts owing to the hampered free rotation of the piperidine fragment.

The diagnostic $\mathrm{NH}$ proton formed upon the proton transfer from piperidine to the isocyanide nitrogen resonates within 7.78-8.04 ppm (see Scheme 2). Moreover, the observed cross-peak between $\mathrm{NH}$ and $\mathrm{H}^{6}$ pip in NOESY experiments suggests for the $[\mathrm{Au}(\mathrm{NHC})(\mathrm{NAC})]^{+}$complexes an endo conformation, ${ }^{11}$ which is confirmed by the structural determination (vide infra). The NAC aromatic protons also display an upfield shift when compared with the corresponding DIC derivatives. Generally speaking, the NHC-NAC derivatives display an upfield shift of the signals of protons of the $\mathrm{NHC}$ imidazolium $\mathrm{CH}$ or imidazolinium $\mathrm{CH}_{2}$ of the 
Table 1. Selected ${ }^{1} \mathrm{H}$ and ${ }^{13} \mathrm{C}$ NMR Signals at $298 \mathrm{~K}$ in $\mathrm{CDCl}_{3}$ for the Complexes under Study

\begin{tabular}{|c|c|c|c|c|c|c|c|c|c|c|c|c|}
\hline & $\mathrm{CH}$ & $\mathrm{CH}_{2}$ & $\mathrm{H}^{d}$ & $\mathrm{NH}$ & $\mathrm{H}_{\text {pip }}^{2}$ & $\mathrm{H}_{\text {pip }}^{6}$ & $\mathrm{CH}$ & $\mathrm{CH}_{2}$ & $\mathrm{C}^{a}$ & $\mathrm{C}^{d}$ & $\mathrm{NC} \mathrm{N}_{\mathrm{NHC}}$ & $\mathrm{NC} \mathrm{N}_{\mathrm{NAC}}$ \\
\hline $\begin{array}{l}{[\mathrm{Au}(\mathrm{SIMes})(\mathrm{DIC})] \mathrm{BF}_{4}} \\
{[\mathrm{Au}(\mathrm{IMes})(\mathrm{DIC})] \mathrm{BF}_{4}} \\
{[\mathrm{Au}(\mathrm{SIPr})(\mathrm{DIC})] \mathrm{BF}_{4}} \\
{[\mathrm{Au}(\mathrm{IPr})(\mathrm{DIC})] \mathrm{BF}_{4}} \\
{\left[\mathrm{Au}(\mathrm{SIMes})\left\{\mathrm{C}\left(\mathrm{NHR}^{\prime}\right)\left(\mathrm{NR}^{\prime}{ }_{2}\right)\right\}\right] \mathrm{BF}_{4}} \\
{\left[\mathrm{Au}(\mathrm{IMes})\left\{\mathrm{C}\left(\mathrm{NHR}_{4}\right)\left(\mathrm{NR}^{\prime}{ }_{2}\right)\right\}\right] \mathrm{BF}_{4}} \\
{\left[\mathrm{Au}(\mathrm{SIPr})\left\{\mathrm{C}(\mathrm{NHR})\left(\mathrm{NR}_{2}\right)\right\}\right] \mathrm{BF}_{4}} \\
{\left[\mathrm{Au}(\mathrm{IPr})\left\{\mathrm{C}(\mathrm{NHR})\left(\mathrm{NR}^{\prime}{ }_{2}\right)\right\}\right] \mathrm{BF}_{4}} \\
{[\mathrm{Au}(\mathrm{SIMes}) \mathrm{Cl}]} \\
{[\mathrm{Au}(\mathrm{IMes}) \mathrm{Cl}]} \\
{[\mathrm{Au}(\mathrm{SIPr}) \mathrm{Cl}]} \\
{[\mathrm{Au}(\mathrm{IPr}) \mathrm{Cl}]}\end{array}$ & $\begin{array}{l}7.46 \\
7.63 \\
7.07 \\
7.19 \\
7.09 \\
7.18\end{array}$ & $\begin{array}{l}4.28 \\
4.40 \\
3.92 \\
4.02 \\
3.98 \\
4.06\end{array}$ & $\begin{array}{l}7.34 \\
7.35 \\
7.48 \\
7.36 \\
7.00 \\
6.95 \\
6.76 \\
6.77\end{array}$ & $\begin{array}{l}7.84 \\
8.04 \\
7.78 \\
7.89\end{array}$ & $\begin{array}{l}3.44 \\
3.45 \\
2.93 \\
3.01\end{array}$ & $\begin{array}{l}3.48 \\
3.54 \\
3.43 \\
3.48\end{array}$ & $\begin{array}{l}122.7 \\
123.9 \\
122.2 \\
123.3^{b}\end{array}$ & $\begin{array}{l}51.8 \\
54.7 \\
50.9 \\
53.7\end{array}$ & $\begin{array}{l}123.2 \\
123.2 \\
124.5 \\
a \\
136.4 \\
137.3 \\
136.4 \\
136.6\end{array}$ & $\begin{array}{l}131.8 \\
131.7 \\
131.9 \\
131.9 \\
127.5 \\
127.4 \\
127.8 \\
127.7\end{array}$ & $\begin{array}{l}199.2 \\
177.4 \\
199.4 \\
178.6 \\
207.4 \\
185.9 \\
207.9 \\
187.4 \\
195.0 \\
173.4 \\
196.1 \\
175.1^{b}\end{array}$ & $\begin{array}{l}201.2 \\
201.2 \\
200.6 \\
200.4\end{array}$ \\
\hline
\end{tabular}

${ }^{a}$ Not detectable. ${ }^{b}$ In $\mathrm{CD}_{2} \mathrm{Cl}_{2}$.

\section{Scheme 2}<smiles></smiles>
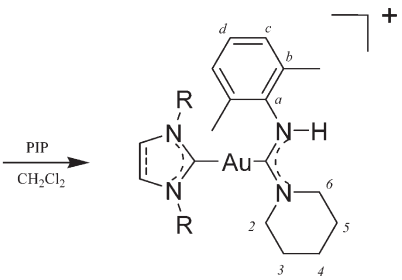

bis-carbene derivatives $[\mathrm{Au}(\mathrm{NHC})(\mathrm{NAC})]^{+}$with respect to the starting complexes $[\mathrm{Au}(\mathrm{NHC})(\mathrm{DIC})]^{+}$. Similarly, an upfield shift is also noticed in the case of the mesityl $\mathrm{CH}_{3}$ or methyl isopropyl $\left(\mathrm{CH}_{3}\right)_{2} \mathrm{CH}$ protons of the NHC substituents. However, such a general behavior is no longer valid when the ${ }^{13} \mathrm{C}$ NMR spectra of the bis-carbene complexes are taken into consideration. As a matter of fact, the NHC carbene carbon of the species [Au(IMes) $\left\{\mathrm{C}(\mathrm{NHAr})\left(\mathrm{NC}_{5^{-}}\right.\right.$ $\left.\left.\left.\mathrm{H}_{10}\right)\right\}\right]^{+}$resonates downfield $(\sim 8.5 \mathrm{ppm})$ with respect to the corresponding $[\mathrm{Au}(\mathrm{IMes})(\mathrm{DIC})]^{+}$complex, whereas the NAC carbene carbons resonate at frequencies similar to those of other NAC derivatives described in the literature. ${ }^{11 \mathrm{~d}-\mathrm{f}}$ The signals ascribable to the carbene carbons of the NAC derivatives display an intense cross-peak with the $\mathrm{NH}$ proton (HMBC experiments) and resonate at higher field (6-7 ppm) with respect to the carbene carbons of the saturated NHC and at lower field $(13-15 \mathrm{ppm})$ with respect to those of the unsaturated species.

The disappearance of the IR band at ca. $2200 \mathrm{~cm}^{-1}$ and the appearance of a band related to the $v_{\mathrm{CN}}$ band of the NAC fragment at ca. $1550 \mathrm{~cm}^{-1}$ confirms the amine insertion.

Crystal Structure Determinations. ORTEP ${ }^{15}$ views of the complexes $\left[\mathrm{Au}(\mathrm{IMes}) \mathrm{DIC}_{\mathrm{BF}} \mathrm{B}_{4}\right.$ and $\left[\mathrm{Au}(\mathrm{IMes})\left\{\mathrm{C}\left(\mathrm{NHC}_{6^{-}}\right.\right.\right.$ $\left.\left.\left.\mathrm{H}_{3}(\mathrm{Me})_{2}\right)\left(\mathrm{NC}_{5} \mathrm{H}_{10}\right)\right\}\right] \mathrm{BF}_{4}$ are shown in Figures 1 and 2, and selected bond distances and angles are reported in Table 2.

In the complex $[\mathrm{Au}(\mathrm{IMes}) \mathrm{DIC}] \mathrm{BF}_{4}$ the coordination about $\mathrm{Au} 1$ is almost linear, with a $\mathrm{C} 1-\mathrm{Au} 1-\mathrm{C} 22$ bond angle of $176.5(2)^{\circ}$. The two mesityl rings are rotated with respect to the

(15) Burnett, M. N.; Johnson, C. K. ORTEP III, Report ORNL6895; Oak Ridge National Laboratory, Oak Ridge, TN, 1996.

(16) (a) Catalano, V. J.; Malwitz, M. A.; Etogo, A. O. Inorg. Chem. 2004, 43, 5714-5724. (b) Baker, M. V.; Barnard, P. L.; Berners-Price, S. J.; Brayshaw, S. K.; Hickey, J. L.; Skelton, B. W.; White, A. H. Dalton Trans. 2006, 3708-3715. (c) Catalano, V. J.; Etogo, A. O. Inorg. Chem. 2007, 46, 5608-5615. (d) Partyka, D. V.; Esswein, A. J.; Zeller, M.; Hunter, A. D.; Gray, T. G. Organometallics 2007, 26, 3279-3282. (e) Akana, J. A.; Bhattacharyya, K. X.; Müller, P.; Sadighi, J. P. J. Am. Chem. Soc. 2007, 129, 7736-7737. (f) Tsui, E. Y.; Müller, P.; Sadighi, J. P. Angew. Chem., Int. Ed. 2008, 47, 8937-8940.

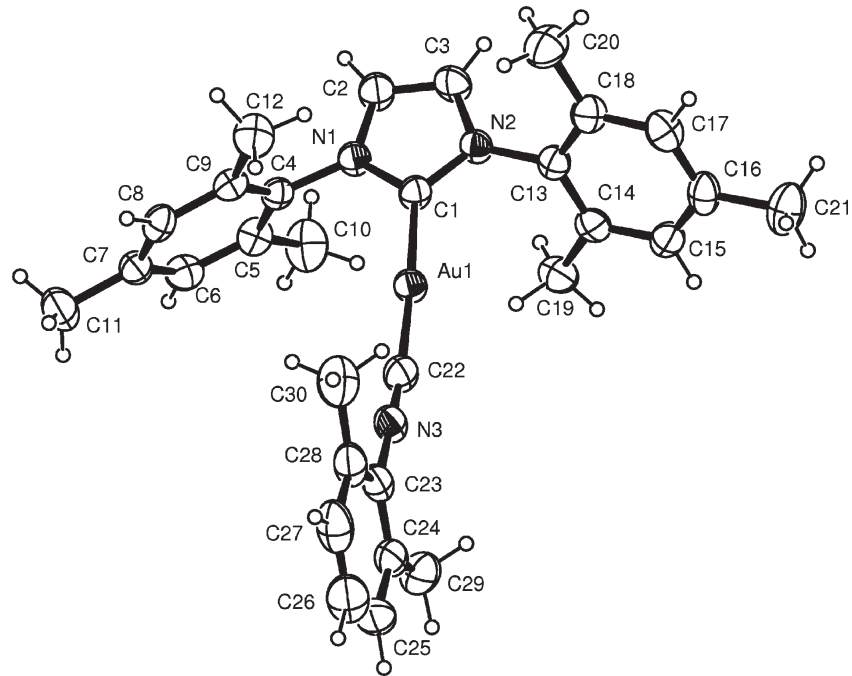

Figure 1. ORTEP ${ }^{15}$ view of the cation of complex $\left[\mathrm{Au}(\mathrm{IMes}) \mathrm{DIC}_{\mathrm{B}} \mathrm{BF}_{4}\right.$, showing thermal ellipsoids at the $30 \%$ probability level.

imidazole plane by $81.0(2)$ and $67.9(2)^{\circ}$, while the 2,6-dimethylphenyl isocyanide moiety is almost perpendicular, making an angle of $81.9(2)^{\circ}$ with the $\mathrm{NHC}$ ring. The Au1-C1(carbene) distance of $1.998(5) \AA$ is slightly shorter than the corresponding distances in similar compounds, ${ }^{16}$ while the shorter Au1-C22 bond length can be accounted for in terms of sp hybridization of the isocyanide carbon $\mathrm{C} 22$.

Also, in the complex [Au(IMes) $\left\{\mathrm{C}\left(\mathrm{NHC}_{6} \mathrm{H}_{3}(\mathrm{Me})_{2}\right)-\right.$ $\left.\left.\left(\mathrm{NC}_{5} \mathrm{H}_{10}\right)\right\}\right] \mathrm{BF}_{4}$ the coordination about the $\mathrm{Au} 1$ is almost linear with a $\mathrm{C} 1-\mathrm{Au} 1-\mathrm{C} 22$ bond angle of $176.6(2)^{\circ}$. The two mesityl rings are rotated with respect to the imidazole ring by 89.7(2) and $77.4(2)^{\circ}$. Both $\mathrm{Au}-$ carbene distances, $\mathrm{Au} 1-\mathrm{C} 1$ and Au1-C22 (2.018(6) and 2.032(6) А), are in perfect agreement with other similar distances in $\mathrm{Au}(\mathrm{I})$ carbene complexes. ${ }^{16}$

Kinetic Measurements. Owing to the reduced concentrations, the reactions carried out by $\mathrm{UV}$-vis techniques were slow and easily measurable. However, preliminary experiments displayed a detectable and immediate decrease of absorbance upon addition of the amine to the solution of the starting complexes, followed by a slow, smooth reaction, yielding eventually the typical spectral features of the independently synthesized bis-carbene NHC-NAC derivatives (Figure 3).

In any case the progress of these reactions and the related changes in concentration of the complex $[\mathrm{Au}(\mathrm{NHC})(\mathrm{DIC})]^{+}$ 


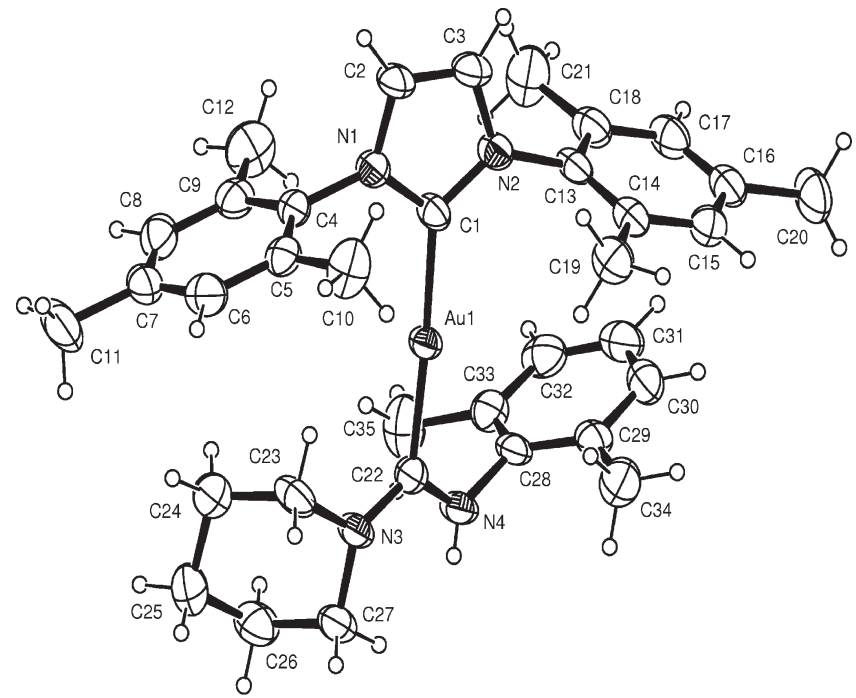

Figure 2. ORTEP ${ }^{15}$ view of the cation of the complex [Au(IMes)$\left.\left\{\mathrm{C}\left(\mathrm{NHC}_{6} \mathrm{H}_{3}(\mathrm{Me})_{2}\right)\left(\mathrm{NC}_{5} \mathrm{H}_{10}\right)\right\}\right] \mathrm{BF}_{4}$, showing thermal ellipsoids at the $30 \%$ probability level.

Table 2. Selected Bond Distances ( $⿱$ $)$ and Angles (deg)

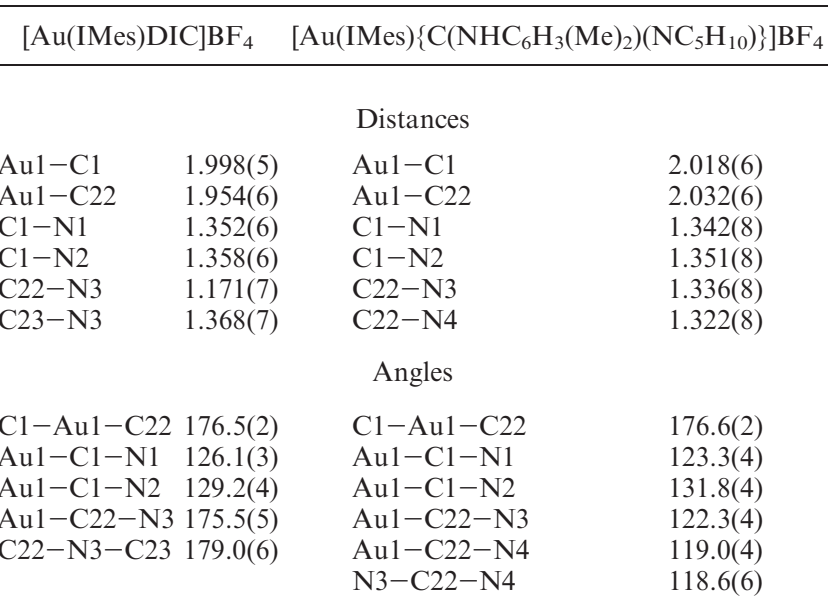

with time ([Amines $]_{0} \geq 10[\text { complex }]_{0}$, pseudo-first-order conditions), are described by the first-order rate law

$$
-\frac{\mathrm{d}[\text { complex }]}{\mathrm{d} t}=k_{\mathrm{obs}}[\text { complex }]
$$

which in terms of absorbance changes takes the form

$$
D_{t}=\left(D_{0}-D_{\infty}\right) e^{-k_{\mathrm{obs}} t}+D_{\infty}
$$

where $D_{0}, D_{\infty}$, and $D_{t}$ are the absorbances at $t=0$, at the end of the reaction $(t=\infty)$ and at time $t$. The ensuing $k_{\text {obs }}$ values for the reaction of the complex $[\mathrm{Au}$ (SIMes)(DIC) $] \mathrm{BF}_{4}$ and piperidine were fitted to the piperidine concentration, and the linear dependence shown in Figure 4 was observed.

The instantaneous decrease of the absorbance observed upon addition of piperidine to the solution under study and the intercept in Figure.4 strongly suggest that the piperidine attack at the gold complex occurs at least via two independent paths. In order to better understand the reaction mechanism, we decided to study a reaction slower than that involving piperidine and the complex $[\mathrm{Au}(\mathrm{SIMes})(\mathrm{DIC})] \mathrm{BF}_{4}$. We therefore resorted to the isostructural but less basic morpholine reacting with the complex $[\mathrm{Au}(\mathrm{IPr})(\mathrm{DIC})] \mathrm{BF}_{4}$. In this case also

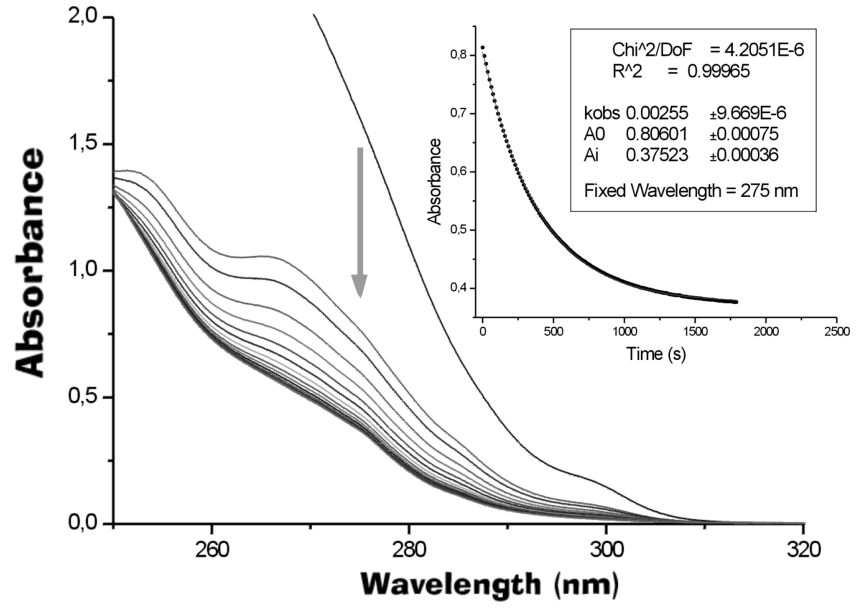

Figure 3. Absorbance changes as a function of time at $25^{\circ} \mathrm{C}$ in $\mathrm{CHCl}_{3}$ for the reaction $[\mathrm{Au}$ (IMes)(DIC) $] \mathrm{BF}_{4}+\mathrm{PIP} \rightarrow[\mathrm{Au}$ (IMes)$\left.\left\{\mathrm{C}\left(\mathrm{NHC}_{6} \mathrm{H}_{3}(\mathrm{Me})_{2}\right)\left(\mathrm{NC}_{5} \mathrm{H}_{10}\right)\right\}\right] \mathrm{BF}_{4}$. Insert: time dependence of absorbance at $\lambda 275 \mathrm{~nm}$ ([[Au(IMes)(DIC) $\left.] \mathrm{BF}_{4}\right]_{0}=1 \times 10^{-4}$ $\left.\mathrm{mol} \mathrm{dm}{ }^{-3},[\mathrm{PIP}]=2 \times 10^{-3} \mathrm{~mol} \mathrm{dm}^{-3} ; \Delta t=120 \mathrm{~s}\right)$.

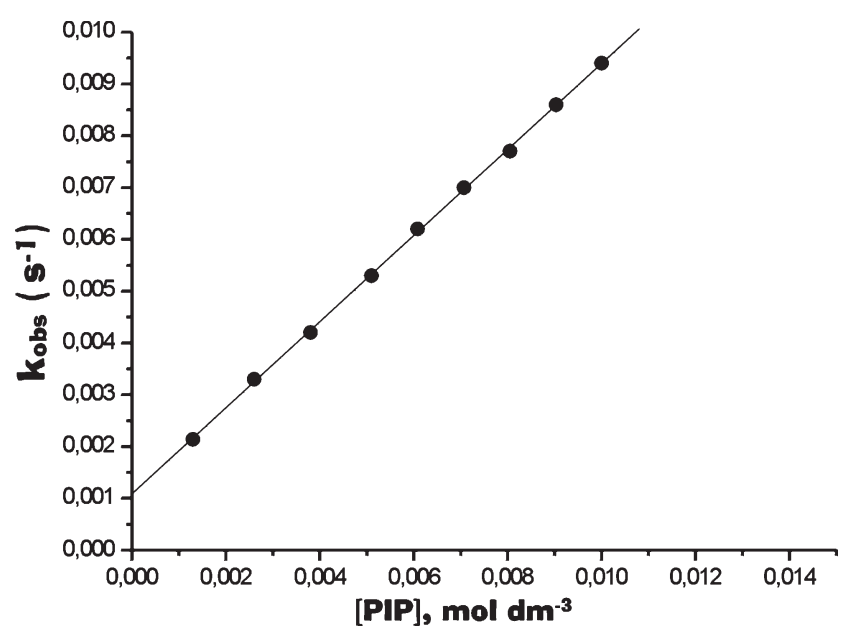

Figure 4. Linear dependence of $k_{\mathrm{obs}}$ on piperidine concentration for the reaction between $[\mathrm{Au}(\mathrm{SIMes})(\mathrm{DIC})] \mathrm{BF}_{4}$ and piperidine in $\mathrm{CHCl}_{3}$ at $25^{\circ} \mathrm{C}$.

the instantaneous absorbance change (although less marked than that previously observed) is followed by a smooth reaction, yielding the NHC-NAC derivative. In this case, the dependence of $k_{\text {obs }}$ on morpholine concentration is shown in Figure 5.

The $k_{\text {obs }}$ dependence on the entering amine concentration $\left[\mathrm{NHR}^{\prime}{ }_{2}\right]_{0}$ can be represented by a nonlinear function of the type given by eq 3 , which describes appropriately the features of Figure 5.

$$
k_{\mathrm{obs}}=\frac{a\left[\mathrm{NHR}_{2}^{\prime}\right]+b\left[\mathrm{NHR}_{2}^{\prime}\right]^{2}}{1+c\left[\mathrm{NHR}_{2}^{\prime}\right]}
$$

Among the different mechanisms that are reasonably conceivable in agreement with the experimental findings, we propose the stepwise network given by Scheme 3 .

Of course, the intermediates $\mathbf{I}_{\mathbf{2}}$ and $\mathbf{I}_{\mathbf{3}}$ in Scheme 3 might as well be replaced by the corresponding transition states, since none of them could be identified experimentally. 


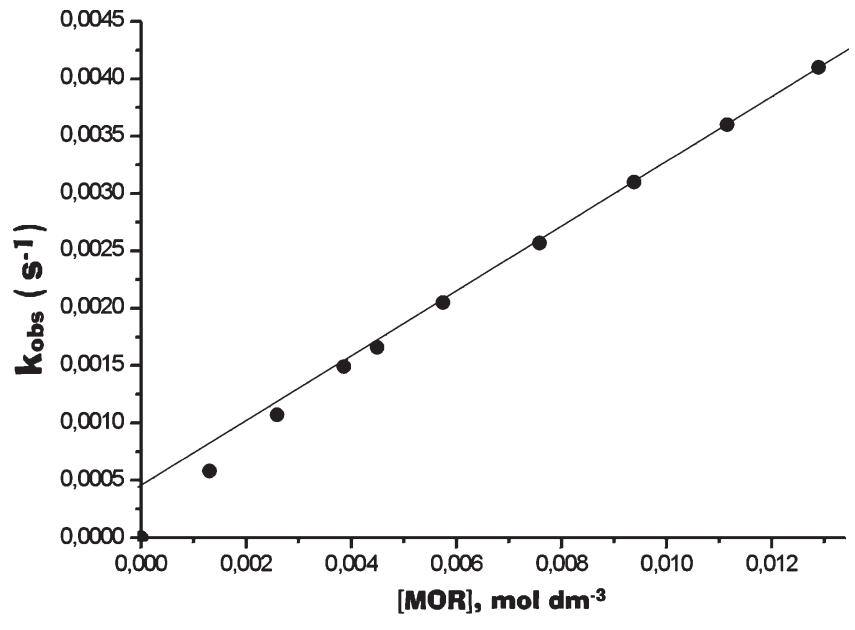

Figure 5. Dependence of $k_{\mathrm{obs}}$ on morpholine concentration for the reaction between $[\mathrm{Au}(\mathrm{IPr})(\mathrm{DIC})] \mathrm{BF}_{4}$ and morpholine in $\mathrm{CHCl}_{3}$ at $25^{\circ} \mathrm{C}$.

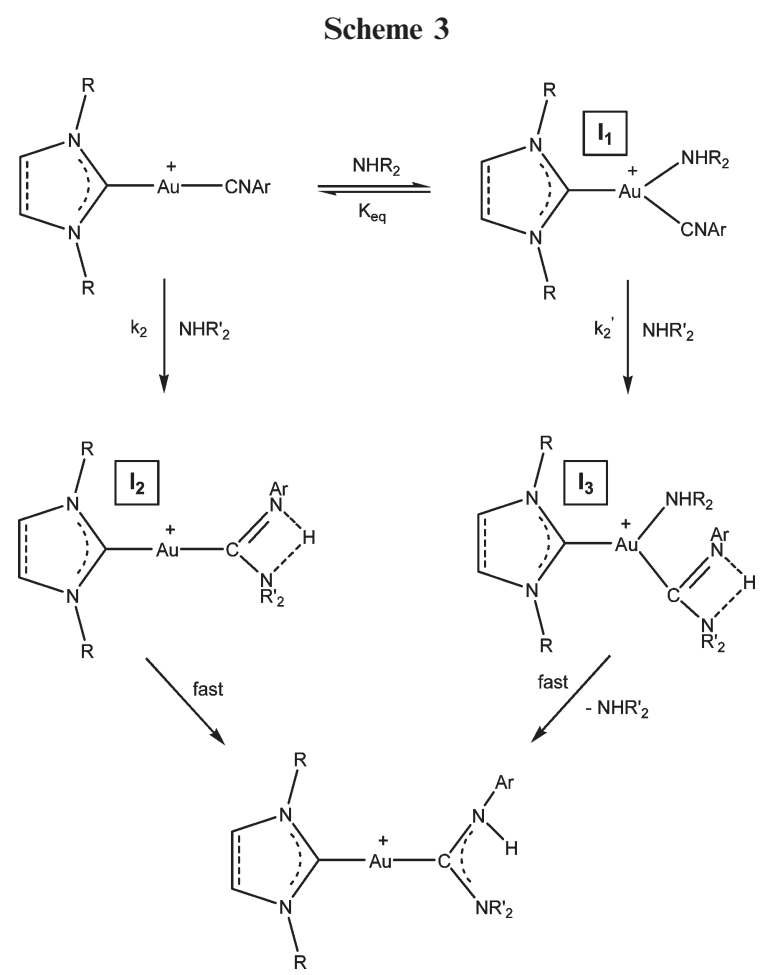

The $a, b$, and $c$ parameters of eq 3 become $k_{2}, k_{2}{ }^{\prime} K_{\text {eq }}$, and $K_{\text {eq }}$, respectively. A nonlinear regression analysis of the data in Figure 2 carried out under the SCIENTIST environment is given in Figure 6.

The values of the calculated parameters are $k_{2}=0.59 \pm$ $0.02 \mathrm{~mol}^{-1} \mathrm{dm}^{3} \mathrm{~s}^{-1}, k_{2}^{\prime}=0.246 \pm 0.003 \mathrm{~mol}^{-1} \mathrm{dm}^{3} \mathrm{~s}^{-1}$, and $K_{\text {eq }}=404 \pm 52$.

However, since the nonlinear regression parameters are highly correlated (mainly $k_{2}{ }^{\prime}$ and $K_{\text {eq }}$ ), we decided to determine the value of $K_{\text {eq }}$ independently by spectrophotometric titration at $298 \mathrm{~K}$ of isotonic solutions of the complex under study with increasing amounts of amine, taking advantage of the marked change in absorbance observable upon amine addition and of the slowness of the subsequent reaction. The regression analysis of absorbance vs amine concentration was carried out according to a general model which is

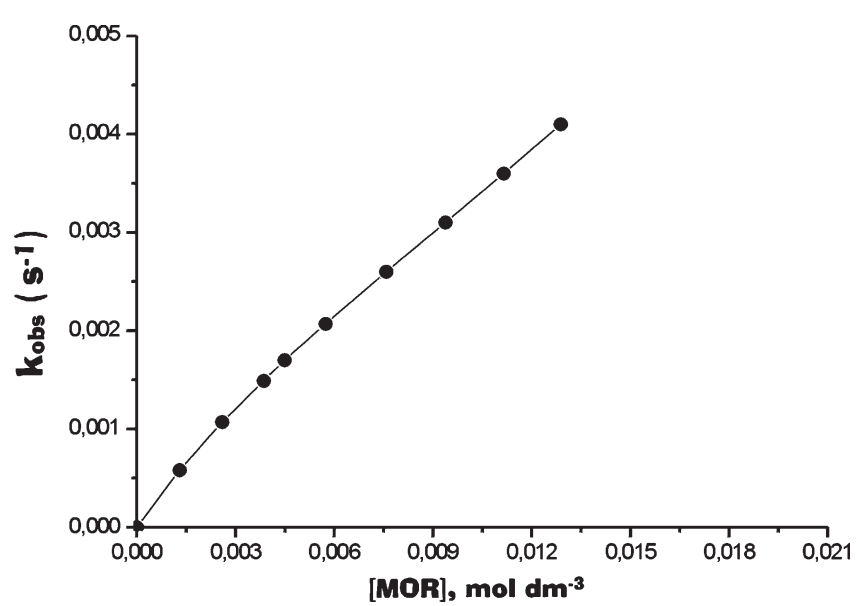

Figure 6. Nonlinear regression analysis based on eq 3 for the reaction between $[\mathrm{Au}(\mathrm{IPr})(\mathrm{DIC})] \mathrm{BF}_{4}$ and morpholine in $\mathrm{CHCl}_{3}$ at $25^{\circ} \mathrm{C}$.

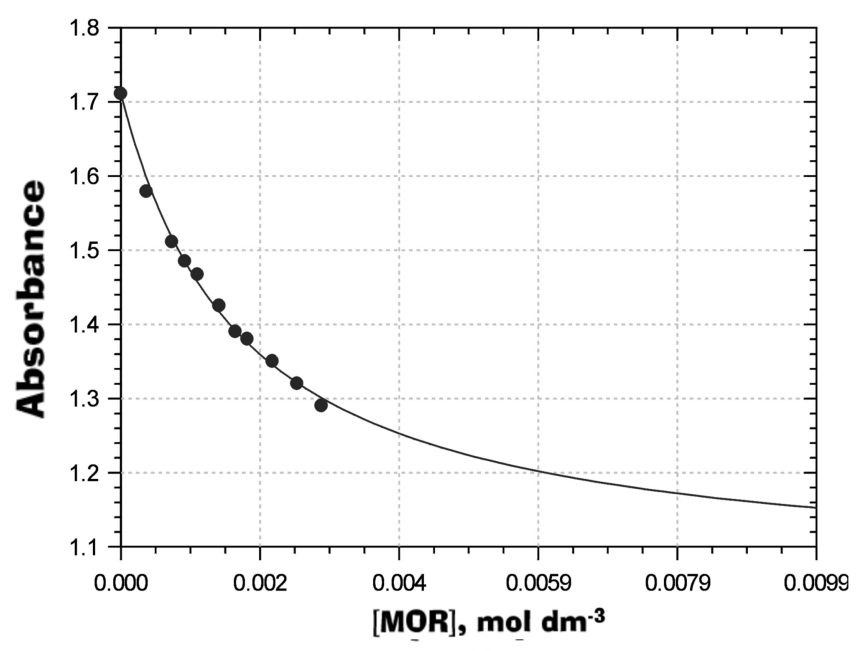

Figure 7. Regression analysis for the titration of the complex $[\mathrm{Au}(\mathrm{IPr})(\mathrm{DIC})] \mathrm{BF}_{4}$ with morpholine in $\mathrm{CHCl}_{3}$ at $25^{\circ} \mathrm{C}$.

described here:

$$
\begin{gathered}
{\left[[\mathrm{Au}(\mathrm{NHC})(\mathrm{DIC})]^{+}\right]_{0}=\left[[\mathrm{Au}(\mathrm{NHC})(\mathrm{DIC})]^{+}\right]+\left[\mathbf{I}_{1}\right]} \\
{\left[\mathrm{NHR}_{2}\right]_{0}=\left[\mathrm{NHR}_{2}{ }^{\prime}\right]+\left[\mathbf{I}_{1}\right]} \\
K_{\mathrm{eq}}=\left[\mathbf{I}_{1}\right] /\left[[\mathrm{Au}(\mathrm{NHC})(\mathrm{DIC})]^{+}\right]\left[\mathrm{NHR}_{2}{ }^{\prime}\right] \\
D_{i}=\varepsilon_{[\mathrm{Au}(\mathrm{NHC})(\mathrm{DIC})]}\left[[\mathrm{Au}(\mathrm{NHC})(\mathrm{DIC})]^{+}\right]+\varepsilon_{\mathbf{I} 1}\left[\mathbf{I}_{1}\right]
\end{gathered}
$$

where $D_{i}$ is the absorbance at any addition of amine and $\varepsilon_{[\mathrm{Au}(\mathrm{NHC})(\mathrm{DIC})]}$ and $\varepsilon_{\mathbf{I 1}}$ are the molar extinction coefficients of the complexes $[\mathrm{Au}(\mathrm{NHC})(\mathrm{DIC})] \mathrm{BF}_{4}$ and $\mathbf{I}_{1}$, respectively, the equilibrium constant $K_{\mathrm{eq}}$ and $\varepsilon_{\mathbf{I} \mathbf{1}}$ being the parameters to be optimized.

The graphical outcome for the titration of [Au(IPr)(DIC)] $\mathrm{BF}_{4}$ with morpholine in $\mathrm{CHCl}_{3}$ is reported in Figure 7.

Notably, the titration is far from complete, since the rate of the subsequent amination reaction increases with the amine concentration. Nevertheless, we were able to determine the equilibrium constants for all the complexes synthesized (see Table 3 and the Experimental Section), although with a marked uncertainty $(\geq 10 \%)$. 
Table 3. Equilibrium Constants $K_{\text {eq }}$ for the Reaction

$[\mathrm{Au}(\mathrm{NHC})(\mathrm{DIC})] \mathrm{BF}_{4}+\mathrm{NHR}_{2}^{\prime}=\mathbf{I}_{1}$

\begin{tabular}{llcc}
\hline \multicolumn{1}{c}{ complex } & \multicolumn{1}{c}{$\operatorname{PIP}\left(11.2^{a}\right)$} & DEA $\left(10.49^{a}\right)$ & MOR $\left(8.33^{a}\right)$ \\
\hline$[\mathrm{Au}(\mathrm{SIMes})(\mathrm{DIC})] \mathrm{BF}_{4}$ & $10781 \pm 1402$ & $4366 \pm 310$ & $747 \pm 130$ \\
{$[\mathrm{Au}(\mathrm{IM})(\mathrm{DIC})] \mathrm{BF}_{4}$} & $10634 \pm 1595$ & $3445 \pm 852$ & $514 \pm 152$ \\
{$[\mathrm{Au}(\mathrm{SIPr})(\mathrm{DIC})] \mathrm{BF}_{4}$} & $11354 \pm 506$ & $7643 \pm 953$ & $782 \pm 62$ \\
{$\left[\mathrm{Au}(\mathrm{IPr})(\mathrm{DIC}) \mathrm{BF}_{4}\right.$} & $11726 \pm 1110$ & $6958 \pm 770$ & $600 \pm 62$
\end{tabular}

${ }^{a} \mathrm{p} K_{\mathrm{a}}$ of the amines in water.

The knowledge of the equilibrium constants removes the high correlation between parameters and allows the complete redetermination of the parameters in eq 3 , as reported in Tables 4 and 5.

Nature of the Intermediates. The fast equilibrium reaction between the starting complexes $[\mathrm{Au}(\mathrm{NHC})(\mathrm{DIC})] \mathrm{BF}_{4}$ and the amines can be interpreted as a fast nucleophilic attack of the secondary amine at the metal center leading to the formation of the trigonal species $\mathbf{I}_{\mathbf{1}}$ represented in Scheme 3. Although the amine attack is not favored, since hard ligands display scarce affinity for soft metals, at this juncture it might be important to point out that several amine and amino carbene complexes of gold(I) can be found in the literature. ${ }^{17}$ Thus, for the sake of simplicity we represent the intermediate $\mathbf{I}_{\mathbf{1}}$ as a trigonal species bearing the carbene, DIC, and the coordinated amine.

The $K_{\text {eq }}$ values are hardly influenced by the electronic and steric properties of NHC (see Table 3). Again, the steric hindrance of the entering amines does not play any important role, at variance with their basicity which, in contrast, seems to be very important (vide $K_{\text {eq }}(\mathrm{PIP})$ vs $K_{\mathrm{eq}}(\mathrm{MOR})$ ).

In order to get additional clues to the nature of the intermediate, we carried out the spectrophotometric titration of the complex [Au(IPr)(DIC)]BF 4 with $p$-methoxypyridine $\left(K_{\mathrm{eq}}=105 \pm 8 ; \mathrm{p} K_{\mathrm{a}}=6.58\right)$. $p$-Methoxypyridine cannot yield the final bis-carbene complex, owing to its lack of a transferable proton to isocyanide nitrogen (this phenomenon represents the force driving the reaction to completion). The equilibrium is established, and this fact supports the hypothesis of the formation of the three-coordinate gold derivative. Notably, trigonal complexes of gold(I) with phosphine and halides or pseudohalides have been synthesized and characterized. ${ }^{18}$

(17) (a) Ahrens, B.; Jones, P. G.; Fischer, A. K. Eur. J. Inorg. Chem. 1999, 1103-1110. (b) Chiou, J. Z.; Luo, S. C.; You, W. C.; Bhattacharyya, A.; Vasam, C. S.; Huang, C. H.; Lin, I. J. B. Eur. J. Inorg. Chem. 2009, 19501959.

(18) (a) Gimeno, M. C.; Laguna, A. Chem. Rev. 1997, 97, 511-522. (b) Sinha, P.; Wilson, A. K.; Omary, M. A. J. Am. Chem. Soc. 2005, 127, 12488-12489. (c) King, C.; Khan, M. N. I.; Staples, R. J.; Fackler, J. P. Inorg. Chem. 1992, 31, 3236-3238. (d) Forward, J. M.; Assefa, Z.; Fackler, J. P. J. Am. Chem. Soc. 1995, 117, 9103-9104. (e) Baenziger, N. C.; Dittemore, K. M.; Doyle, J. R. Inorg. Chem. 1974, 13, 805-811. (f) Hickey, J. L.; Ruhayel, R. A.; Barnard, P. J.; Baker, M. V.; Berners-Price, S.; Filipovska, A. J. Am. Chem. Soc. 2008, 130, 12570-12571.

(19) An attempt at isolating the intermediate $\mathbf{I}_{1}$ was carried out in $\mathrm{CHCl}_{3}$ by reacting the complex $[\mathrm{Au}(\mathrm{IPr})(\mathrm{DIC})] \mathrm{BF}_{4}$ with a large excess of the unreactive $p$-methoxypyridine. Isolation by precipitation with diethyl ether and/or removal of the solvent yielded no remarkable result. We surmise that the values of the formation constants are strongly determined by the interactions between starting complexes and amines which is mediated by the polar nature of the solvent. In other words, the reorganization of the molecules of solvent around the intermediate $\mathbf{I}_{1}$ would determine a remarkable entropy contribution to the equilibrium constant value. As a matter of fact, large changes in equilibrium constants determined by the different nature of the solvent are not unprecedented. See, for example: Canovese, L.; et al. Eur. J. Inorg. Chem. 2004, 732-742).
Table 4. $k_{2}{ }^{\prime}\left(\mathrm{mol}^{-1} \mathrm{dm}^{3} \mathrm{~s}^{-1}\right)$ Values Calculated with Independently Determined $K_{\text {eq }}$

\begin{tabular}{lccc}
\hline \multicolumn{1}{c}{ complex } & PIP & DEA & MOR \\
\hline$\left[\mathrm{Au}(\right.$ SIMes)(DIC) $] \mathrm{BF}_{4}$ & $0.80 \pm 0.01$ & $0.30 \pm 0.01$ & $0.66 \pm 0.02$ \\
{$[\mathrm{Au}(\mathrm{IMes})(\mathrm{DIC})] \mathrm{BF}_{4}$} & $1.23 \pm 0.03$ & $0.30 \pm 0.01$ & $0.75 \pm 0.03$ \\
{$[\mathrm{Au}(\mathrm{SIPr})(\mathrm{DIC})] \mathrm{BF}_{4}$} & $1.10 \pm 0.01$ & $0.49 \pm 0.01$ & $0.27 \pm 0.01$ \\
{$[\mathrm{Au}(\mathrm{IPr})(\mathrm{DIC})] \mathrm{BF}_{4}$} & $1.16 \pm 0.04$ & $0.29 \pm 0.01$ & $0.26 \pm 0.01$
\end{tabular}

Table 5. $k_{2}\left(\mathrm{~mol}^{-1} \mathrm{dm}^{3} \mathrm{~s}^{-1}\right)$ Values Calculated with Independently Determined $K_{\text {eq }}$

\begin{tabular}{lrcc}
\hline \multicolumn{1}{c}{ complex } & \multicolumn{1}{c}{ PIP } & \multicolumn{1}{c}{ DEA } & \multicolumn{1}{c}{ MOR } \\
\hline$\left[\mathrm{Au}(\right.$ SIMes)(DIC) $] \mathrm{BF}_{4}$ & $13.5 \pm 0.9$ & $2.2 \pm 0.1$ & $0.90 \pm 0.1$ \\
{$\left[\mathrm{Au}(\mathrm{IMes})(\mathrm{DIC}) \mathrm{BF}_{4}\right.$} & $10.5 \pm 1.1$ & $1.2 \pm 0.1$ & $0.60 \pm 0.1$ \\
${\text { [Au(SIPr)(DIC) } \mathrm{BF}_{4}}_{\mathrm{Au}(\mathrm{IPr})(\mathrm{DIC})] \mathrm{BF}_{4}}^{4.7 \pm 0.2}$ & $6.8 \pm 0.9$ & $2.7 \pm 0.2$ & $0.28 \pm 0.03$ \\
{$[\mathrm{Au}$} & $2.5 \pm 0.3$ & $0.68 \pm 0.01$
\end{tabular}

NMR and IR experiments carried out in $\mathrm{CDCl}_{3}$ show a small upfield of signals for DIC isocyanide and a moderate shift at lower frequencies of the $\mathrm{CN}$ stretching, respectively. This effect is not in contrast with the proposed equilibrium reaction and the related $\mathrm{K}_{\mathrm{eq}}$ value. ${ }^{19}$

Regression analysis for the titration of the complex $[\mathrm{Au}(\mathrm{IPr})(\mathrm{DIC})] \mathrm{BF}_{4}$ with $p$-methoxypyridine and the linear free energy relationship between $\mathrm{p} K_{\mathrm{a}}$ and $\log K_{\text {eq }}$ for all the amines involved in the equilibria studied are reported in Figures 8 and 9, respectively.

Apparently the amine attacks the unhindered $[\mathrm{Au}(\mathrm{NHC})-$ $(\mathrm{DIC})]^{+}$cation, yielding a trigonal intermediate whose formation depends only on the $\mathrm{p} K_{\mathrm{a}}$ and is independent of the steric hindrance of the amines.

Intermediate $\mathbf{I}_{\mathbf{2}}$ is the transient species produced by direct associative attack of the amine at the coordinated isocyanide. According to the proposed mechanism the $k_{2}$ values increase with basicity and decrease with the steric bulk of the amine (see Table 5). Such a species rapidly undergoes proton transfer and represents the most obvious intermediate in the formation of NAC derivatives of platinum and palladium. ${ }^{20}$

The nucleophilic attack of a further amine molecule at the isocyanide carbon of intermediate $\mathbf{I}_{\mathbf{1}}$ yields the intermediate $\mathbf{I}_{\mathbf{3}}$ (see Scheme 3 ). Intermediate $\mathbf{I}_{\mathbf{3}}$ rapidly collapses into the final bis-carbene derivative $[\mathrm{Au}(\mathrm{NHC})(\mathrm{NAC})]^{+}$upon release of the amine coordinated to the crowded gold center and concomitant proton transfer. Incidentally, the overcrowded structure of the complex $\left[\mathrm{Au}(\mathrm{IMes})\left\{\mathrm{C}(\mathrm{NHAr})\left(\mathrm{NC}_{5} \mathrm{H}_{10}\right)\right\}\right] \mathrm{BF}_{4}$ seems to confirm such a hypothesis (see Crystal Structure Determinations). The similar values of reaction rate constants $k_{2}{ }^{\prime}$ might stem from the enhanced electronic density on the metal induced by the already coordinated amine (see Table 4). Such an increase in electronic density parallels the basicity of the amine itself, and consequently the isocyanide carbon becomes less prone to nucleophilic attack by one further amine, giving rise to some sort of leveling effect. Furthermore, in this case some anchimeric assistance exerted by the metal-coordinated amine in the proton transfer process cannot be ruled out a priori. ${ }^{20 a}$

(20) (a) Canovese, L.; Visentin, F.; Uguagliati, P.; Crociani, B.; Di Bianca, F. J. Organomet. Chem. 1997, 535, 69-75. (b) Busetto, L.; Palazzi, A.; Crociani, B.; Belluco, U.; Badley, E. M.; Kilby, B. J. L.; Richards, R. L. J. Chem. Soc., Dalton Trans. 1972, 1800-1805. (c) Bertani, R.; Mozzon, M.; Michelin, R. A. Inorg. Chem. 1988, 27, 2809-2815. (d) Michelin, R. A.; Pombeiro, A. J. L.; Guedes da Silva, M. F. C. Coord. Chem. Rev. 2001, 218 , 75-112. (e) Crociani, B.; Boschi, T.; Nicolini, M.; Belluco, U. Inorg. Chem. 1972, 6, 1292-1296. (f) Calligaro, L.; Uguagliati, P.; Crociani, B.; Belluco, U. J. Organomet. Chem. 1975, 92, 399-408. (g) Uguagliati, P.; Crociani, B.; Belluco, U.; Calligaro, L. J. Organomet. Chem. 1976, 112, 111-121. 


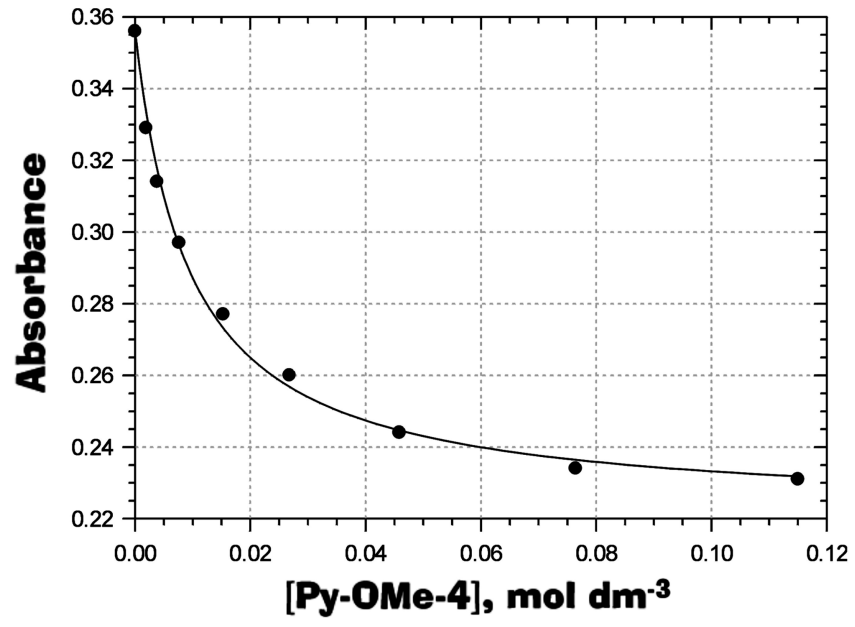

Figure 8. Regression analysis for the titration of the complex $[\mathrm{Au}(\mathrm{IPr})(\mathrm{DIC})] \mathrm{BF}_{4}$ with $p$-methoxypyridine in $\mathrm{CHCl}_{3}$ at $25^{\circ} \mathrm{C}$.

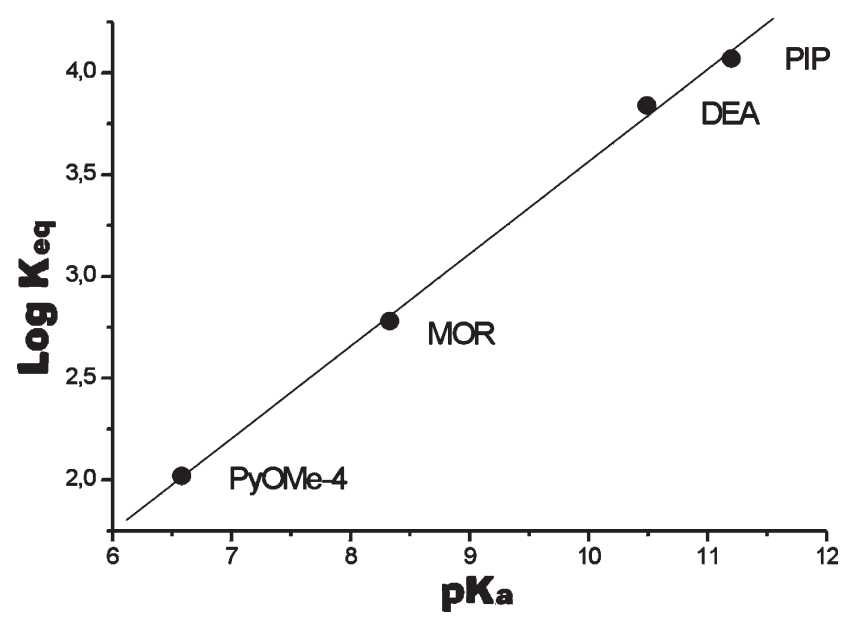

Figure 9. Free energy linear relationship between $\mathrm{p} K_{\mathrm{a}}$ and $\log$ $K_{\text {eq }}$ for the equilibrium $[\mathrm{Au}(\mathrm{IPr})(\mathrm{DIC})] \mathrm{BF}_{4}+\mathrm{am}=[\mathrm{Au}(\mathrm{IPr})-$ (DIC)(am) $] \mathrm{BF}_{4}$.

\section{Conclusions}

We have synthesized and characterized several new gold(I) complexes with the carbene NHC and isocyanide DIC as ligands. These species were reacted with secondary amines $\mathrm{NHR}_{2}$ to yield unprecedented mixed bis-carbene NHCNAC gold(I) derivatives under mild experimental conditions. In the case of the reaction between the complexes [Au(NHC)$(\mathrm{DIC})]^{+}$and piperidine the bis-carbene products were separated and fully characterized. On the basis of a detailed kinetic study the mechanism of formation of the bis-carbene derivatives was proposed. The nonlinear complex dependence of the measured $k_{\text {obs }}$ value on amine concentration suggests that a concomitant attack at the coordinated isocyanide $\left(k_{2}\right)$ and at the metal center takes place $\left(K_{\text {eq }}\right.$, fast). The trigonal adduct formed as a consequence of the fast amine attack at gold undergoes a further attack of the amine at the coordinated isocyanide $\left(k_{2}{ }^{\prime}\right)$. Both of the resulting intermediates rapidly collapse to the final biscarbene NHC-NAC derivatives.

The independent determination of $K_{\text {eq }}$ by direct spectrophotometric titration of the starting complexes with the amines under study allows the complete determination of all constants involved in the mechanistic network.
The structures of the complexes [Au(IMes)DIC) $] \mathrm{BF}_{4}$ and $\left[\mathrm{Au}(\mathrm{IMes})\left\{\mathrm{C}(\mathrm{NHAr})\left(\mathrm{NC}_{5} \mathrm{H}_{10}\right)\right\}\right] \mathrm{BF}_{4}$ are also reported in the paper.

\section{Experimental Section}

Solvents and Reagents. $\mathrm{CH}_{2} \mathrm{Cl}_{2}$ was distilled over $\mathrm{CaH}_{2}$ under an inert atmosphere (Ar). $\mathrm{CHCl}_{3}$ was distilled and stored over silver foil. Piperidine, morpholine, and diethylamine were distilled over $\mathrm{KOH}$ under an inert atmosphere (Ar). All other chemicals were commercially available products unless otherwise stated. [Au(SIMes)Cl], [Au(IMes)Cl], [Au(IPr)Cl], and $[\mathrm{Au}(\mathrm{SIPr}) \mathrm{Cl}]$ were prepared following literature procedures. ${ }^{7 \mathrm{c}}$

IR, NMR, and UV-vis Measurements. The IR and ${ }^{1} \mathrm{H}$ and ${ }^{13} \mathrm{C}\left\{{ }^{1} \mathrm{H}\right\}$ NMR spectra were recorded on a Perkin-Elmer Spectrum One spectrophotometer and on a Bruker 300 Avance spectrometer, respectively. The proton and carbon assignment was performed by ${ }^{1} \mathrm{H}-{ }^{1} \mathrm{H}$ COSY, ${ }^{1} \mathrm{H}-{ }^{1} \mathrm{H}$ NOESY, ${ }^{1} \mathrm{H}-{ }^{13} \mathrm{C}$ $\mathrm{HMBC}$, and ${ }^{1} \mathrm{H}-{ }^{13} \mathrm{C}$ HMQC experiments. UV-vis spectra were measured on a Perkin-Elmer Lambda 40 spectrophotometer equipped with a Perkin-Elmer PTP6 (Peltier temperature programmer) apparatus.

Crystal Structure Determinations. Crystal data of the compounds $[\mathrm{Au}(\mathrm{IMes}) \mathrm{DIC}] \mathrm{BF}_{4}$ and $\left[\mathrm{Au}(\mathrm{IMes})\left\{\mathrm{C}\left(\mathrm{NHC}_{6} \mathrm{H}_{3}(\mathrm{Me})_{2}\right)-\right.\right.$ $\left.\left.\left(\mathrm{NC}_{5} \mathrm{H}_{10}\right)\right\}\right] \mathrm{BF}_{4}$ were collected at room temperature using a Nonius Kappa CCD diffractometer with graphite-monochromated Mo $K \alpha$ radiation. The data sets were integrated with the Denzo-SMN package ${ }^{21}$ and corrected for Lorentz, polarization, and absorption effects $\left(\right.$ SORTAV $\left.^{22}\right)$. The structures were solved by direct methods (SIR97 ${ }^{23}$ ) and refined using full-matrix least squares with all non-hydrogen atoms being refined anisotropically and hydrogens being included on calculated positions, riding on their carrier atoms. In the structure [Au(IMes)$\mathrm{DIC}] \mathrm{BF}_{4}$ the $\mathrm{BF}_{4}{ }^{-}$anion was found to be disordered, and the fluorine atoms were refined isotropically over two positions with occupation factors of 0.5 each. In the structure [Au(IMes)$\left.\left\{\mathrm{C}(\mathrm{NHAr})\left(\mathrm{NC}_{5} \mathrm{H}_{10}\right)\right\}\right] \mathrm{BF}_{4}$ the $\mathrm{NH}$ hydrogen was refined isotropically.

All calculations were performed using SHELXL- $97^{24}$ and PARST $^{25}$ implemented in the WINGX ${ }^{26}$ system of programs. Crystal data are given in Table 1SI (Supporting Information). Selected bond distances and angles are given in Table 2.

Crystallographic data (excluding structure factors) have been deposited at the Cambridge Crystallographic Data Centre and allocated the deposition numbers CCDC 798325-798326. These data can be obtained free of charge via www.ccdc.cam.ac.uk/conts/ retrieving.html or on application to the CCDC, Union Road, Cambridge, CB2 1EZ, U.K. (fax, (+44)1223-336033; e-mail, deposit@ccdc.cam.ac.uk).

Preliminary Studies and Kinetic Measurements. All the nucleophilic attacks were preliminarily analyzed by ${ }^{1} \mathrm{H}$ NMR techniques by dissolving the complex $[\mathrm{Au}(\mathrm{NHC})(\mathrm{DIC})]\left(\mathrm{BF}_{4}\right)$ in $0.8 \mathrm{~mL}_{\text {of }} \mathrm{CDCl}_{3}\left([\text { complex }]_{0} \approx 0.02 \mathrm{~mol} \mathrm{dm}^{-3}\right)$. An appropriate aliquot of the amine $\mathrm{NHR}_{2}^{\prime}\left(\mathrm{NHR}_{2}^{\prime}=\right.$ piperidine, morpholine, diethylamine) was added ([NHR $\left.{ }_{2}\right]_{0} \approx 0.02 \mathrm{~mol} \mathrm{dm}^{-3}$ ), and the reaction was followed to completion by monitoring the signals for the disappearance of the starting complex and the concomitant appearance of those of the $\mathrm{Au}(\mathrm{I})$ bis-carbene complex.

(21) Otwinowski, Z.; Minor, W. In Methods in Enzymology, Carter, C. W., Sweet, R. M., Eds.; Academic Press: London, 1997; Vol. 276, Part A, pp 307-326.

(22) Blessing, R. H. Acta Crystallogr., Sect. A 1995, 51, 33-38.

(23) Altomare, A.; Burla, M. C.; Camalli, M.; Cascarano, G. L.; Giacovazzo, C.; Guagliardi, A.; Moliterni, A. G.; Polidori, G.; Spagna, R. SIR97. J. Appl. Crystallogr. 1999, 32, 115-119.

(24) Sheldrick, G. M. SHELX-97, Program for Crystal Structure Refinement; University of Göttingen, Göttingen, Germany, 1997.

(25) Nardelli, M. J. Appl. Crystallogr. 1995, 28, 659-659.

(26) Farrugia, L. J. J. Appl. Crystallogr. 1999, 32, 837-838. 
An UV-vis preliminary investigation was also carried out, with the aim of determining the wavelength suitable for spectrophotometric determinations. For this purpose, $3 \mathrm{~mL}$ of freshly distilled $\mathrm{CHCl}_{3}$ solution of the complex under study ([complex $]_{0}$ $\approx 1 \times 10^{-4} \mathrm{~mol} \mathrm{dm}^{-3}$ ) was placed in a thermostated $(298 \mathrm{~K})$ cell compartment of the UV-vis spectrophotometer, and aliquots of a concentrated solution of the amine were added $\left(\left[\mathrm{NHR}_{2}^{\prime}\right]_{0} \geq\right.$ $\left.10[\text { complex }]_{0}\right)$. The absorbance change was monitored in the 250-350 nm wavelength interval. The kinetics of nucleophilic attack at fixed wavelength was recorded under pseudo-first $=$ order conditions at $\lambda 290 \mathrm{~nm}$ in the case of the complexes $[\mathrm{Au}(\mathrm{NHC})(\mathrm{DIC})]\left(\mathrm{BF}_{4}\right)(\mathrm{NHC}=\mathrm{SIMes} / \mathrm{SIPr})$ and at $\lambda 275 \mathrm{~nm}$ in the case of the complexes $[\mathrm{Au}(\mathrm{NHC})(\mathrm{DIC})]\left(\mathrm{BF}_{4}\right)(\mathrm{NHC}=$ IMes/IPr), by adding the appropriate aliquots of amine $\left[\mathrm{NHR}_{2}^{\prime}\right]_{0}$ in the concentration interval $0.001-0.01 \mathrm{~mol} \mathrm{dm}^{-3}$ to a freshly prepared $\mathrm{CHCl}_{3}$ solution of the complex under study ([complex $]_{0}$ $\approx 1 \times 10^{-4} \mathrm{~mol} \mathrm{dm}^{-3}$ ).

Equilibrium Measurements. To $3 \mathrm{~mL}$ of prethermostated (298 $\mathrm{K})$ isotonic solutions of the complex under study ([[Au(NHC)$\left.(\mathrm{DIC}) \mathrm{BF}_{4}\right]_{0}=1 \times 10^{-4} \mathrm{~mol} \mathrm{dm}^{-3}$ ) were added different aliquots of concentrated amine solution by means of a micropipet. The $\mathrm{UV}$-vis absorbance values of the ensuing solutions at suitable wavelengths and $298 \mathrm{~K}$ were immediately recorded and analyzed vs the amine concentration data according to the model described in the Results and Discussion. Titrations were stopped when the rate of the subsequent reaction became significant $\left(5 \times 10^{-4} \leq\right.$ $[\mathrm{MOR}]_{0} \leq 3.2 \times 10^{-3} ; 5 \times 10^{-5} \leq[\mathrm{DEA}]_{0} \leq 5 \times 10^{-4} ; 5 \times 10^{-5} \leq$ $[\mathrm{PIP}]_{0} \leq 2.6 \times 10^{-4} \mathrm{~mol} \mathrm{dm}^{-3}$ ).

In the case of the equilibrium between [Au(IPr)(DIC)] and $\mathrm{Py}-\mathrm{OMe}-4$, the titration was driven to completion using pure $\mathrm{Py}-$ OMe-4.

Synthesis of the Complexes. $[\mathrm{Au}(\mathrm{SIMes})(\mathrm{DIC})]\left(\mathrm{BF}_{4}\right)$. To a stirred solution of [Au(SIMes)Cl] $(0.05 \mathrm{~g}, 0.093 \mathrm{mmol})$ and DIC $(0.0146 \mathrm{~g}, 0.111 \mathrm{mmol})$ in dichloromethane $(10 \mathrm{~mL})$ was added solid $\mathrm{AgBF}_{4}(0.020 \mathrm{~g}, 0.102 \mathrm{mmol})$. The reaction proceeds at room temperature with the concomitant precipitation of $\mathrm{AgCl}$. After $15 \mathrm{~min}$ the reaction mixture was treated with activated charcoal and filtered through Celite. The resulting clear solution, concentrated under reduced pressure, yielded the crude product upon addition of diethyl ether. The white residue was filtered off and washed with diethyl ether $(3 \times 3 \mathrm{~mL})$ and $n$ pentane $(3 \times 3 \mathrm{~mL})$. The resulting solid was dried under vacuum.

Yield: $98 \%$, white solid. ${ }^{1} \mathrm{H}$ NMR $\left(\mathrm{CDCl}_{3}, T=298 \mathrm{~K}\right.$, ppm): $\delta 2.30\left(\mathrm{~s}, 6 \mathrm{H}, \mathrm{CH}_{3}{ }^{\mathrm{DIC}}\right), 2.34\left(\mathrm{~s}, 6 \mathrm{H}, \mathrm{CH}_{3}{ }^{\mathrm{SIM}}\right), 2.39(\mathrm{~s}, 12 \mathrm{H}$, $\left.\mathrm{CH}_{3}{ }^{\mathrm{SIM}}\right), 4.28\left(\mathrm{~s}, 4 \mathrm{H}, \mathrm{CH}_{2}\right) 7.01\left(\mathrm{~s}, 4 \mathrm{H}, \mathrm{H}^{\mathrm{SIM}}\right), 7.14\left(\mathrm{~d}, 2 \mathrm{H}, \mathrm{H}^{c}\right.$, $J=7.8 \mathrm{~Hz}), 7.34\left(\mathrm{t}, 1 \mathrm{H}, \mathrm{H}{ }^{d}\right) \cdot{ }^{13} \mathrm{C}\left\{{ }^{1} \mathrm{H}\right\} \mathrm{NMR}\left(\mathrm{CDCl}_{3}, T=298\right.$ $\mathrm{K}, \mathrm{ppm}): \delta 17.9\left(\mathrm{CH}_{3}{ }^{\mathrm{SIM}}\right), 18.5\left(\mathrm{CH}_{3}{ }^{\mathrm{DIC}}\right), 21.0\left(\mathrm{CH}_{3}{ }^{{ }{ }^{2}}\right), 51.8$ $\left(\mathrm{CH}_{2}\right), 123.2\left(\mathrm{C}^{a}\right), 128.5\left(\mathrm{C}^{c}\right), 129.7\left(\mathrm{C}_{\mathrm{SIM}}{ }^{3}\right.$ and $\left.\mathrm{C}_{\mathrm{SIM}}{ }^{5}\right), 131.8$ $\left(\mathrm{C}^{d}\right), 133.8\left(\mathrm{C}_{\mathrm{SIM}}{ }^{4}\right), 135.7\left(\mathrm{C}_{\mathrm{SIM}}{ }^{2}\right.$ and $\left.\mathrm{C}_{\text {SIM }}{ }^{6}\right), 136.3\left(\mathrm{C}^{b}\right), 139.3$ $\left(\mathrm{C}_{\mathrm{SIM}}{ }^{1}\right), 199.2\left(\mathrm{NCN} \mathrm{SIM}_{\mathrm{S}}\right)$. IR ( $\mathrm{KBr}$ pellet, $\left.\mathrm{cm}^{-1}\right): v 2918.7(\mathrm{CH})$, 2224.8 (CN), 1630.7, 1608.7 (CN), 1504.6, 1457.7 (CC), 1082.4, 1060.6 $\left(\mathrm{BF}_{4}\right)$. Anal. Calcd for $\mathrm{C}_{30} \mathrm{H}_{36} \mathrm{AuBF}_{4} \mathrm{~N}_{3}: \mathrm{C}, 49.88 ; \mathrm{H}$, $5.02 ; \mathrm{N}, 5.82$. Found: C, 49.78; H, 4.93; N, 5.86.

The following complexes were prepared under conditions similar to those for $[\mathrm{Au}(\mathrm{SIMes})(\mathrm{DIC})]\left(\mathrm{BF}_{4}\right)$ using the appropriate $[\mathrm{Au}(\mathrm{NHC}) \mathrm{Cl}]$ precursor.

[Au(IMes)(DIC)](BF 4$)$. Yield: $99 \%$, white solid. ${ }^{1} \mathrm{H}$ NMR $\left(\mathrm{CDCl}_{3}, T=298 \mathrm{~K}, \mathrm{ppm}\right): \delta 2.16\left(\mathrm{~s}, 12 \mathrm{H}, \mathrm{CH}_{3}{ }^{\mathrm{IM}}\right), 2.34(\mathrm{~s}, 6 \mathrm{H}$, $\left.\mathrm{CH}_{3}{ }^{\mathrm{DIC}}\right), 2.39\left(\mathrm{~s}, 6 \mathrm{H}, \mathrm{CH}_{3}{ }^{\mathrm{IM}}\right), 7.09\left(\mathrm{~s}, 4 \mathrm{H}, \mathrm{H}^{\mathrm{IM}}\right), 7.16\left(\mathrm{~d}, 2 \mathrm{H}, \mathrm{H}^{c}\right.$, $J=7.50 \mathrm{~Hz}), 7.35\left(\mathrm{t}, 1 \mathrm{H}, \mathrm{H}^{d}\right), 7.46(\mathrm{~s}, 2 \mathrm{H},-\mathrm{HC}=\mathrm{CH}-)$. ${ }^{13} \mathrm{C}\left\{{ }^{1} \mathrm{H}\right\} \operatorname{NMR}\left(\mathrm{CDCl}_{3}, T=298 \mathrm{~K}, \mathrm{ppm}\right): \delta 17.6\left(\mathrm{CH}_{3}{ }^{\mathrm{IM}}\right), 18.5$ $\left(\mathrm{CH}_{3}{ }^{\mathrm{DIC}}\right), 21.1\left(\mathrm{CH}_{3}{ }^{\mathrm{IM}}\right), 123.2\left(\mathrm{C}^{a}\right), 124.8(-\mathrm{HC}=\mathrm{CH}-), 128.5$ $\left(\mathrm{C}^{c}\right), 129.6\left(\mathrm{C}_{\mathrm{IM}}{ }^{3}\right.$ and $\left.\mathrm{C}_{\mathrm{IM}}{ }^{5}\right), 131.7\left(\mathrm{C}^{d}\right), 133.8\left(\mathrm{C}_{\mathrm{IM}}{ }^{4}\right), 134.6$ $\left(\mathrm{C}_{\mathrm{IM}}{ }^{2}\right.$ and $\left.\mathrm{C}_{\mathrm{IM}}{ }^{6}\right), 136.4\left(\mathrm{C}^{b}\right), 140.4\left(\mathrm{C}_{\mathrm{IM}}{ }^{1}\right), 177.4\left(\mathrm{NCN} \mathrm{N}_{\mathrm{IM}}\right)$. IR $\left(\mathrm{KBr}\right.$ pellet, $\left.\mathrm{cm}^{-1}\right): v 2913.7(\mathrm{CH}), 2218.8(\mathrm{CN}), 1608.7(\mathrm{CN})$ 1487.6 (CC), 1082.3, $1037.5\left(\mathrm{BF}_{4}\right)$. Anal. Calcd for $\mathrm{C}_{30} \mathrm{H}_{34} \mathrm{AuBF}_{4} \mathrm{~N}_{3}: \mathrm{C}, 50.02 ; \mathrm{H}, 4.76 ; \mathrm{N}, 5.83$. Found: C, 50.19; $\mathrm{H}, 4.84 ; \mathrm{N}, 5.78$.

[Au(SIPr) (DIC)](BF $\left.\mathbf{B F}_{\mathbf{4}}\right)$. Yield: $98 \%$, white solid. ${ }^{1} \mathrm{H}$ NMR $\left(\mathrm{CDCl}_{3}, T=298 \mathrm{~K}, \mathrm{ppm}\right): \delta 1.38\left(\mathrm{~d}, 12 \mathrm{H}, \mathrm{CH}_{3}{ }^{\mathrm{SIP}}, J=7.1 \mathrm{~Hz}\right)$, $1.41\left(\mathrm{~d}, 12 \mathrm{H}, \mathrm{CH}_{3}{ }^{\mathrm{SIP}}\right), 2.22\left(\mathrm{~s}, 6 \mathrm{H}, \mathrm{CH}_{3}{ }^{\mathrm{DIC}}\right), 3.13$ (sept, $4 \mathrm{H}$, $\left.H \mathrm{C}\left(\mathrm{CH}_{3}\right)_{2}\right), 4.40\left(\mathrm{~s}, 4 \mathrm{H}, \mathrm{CH}_{2}\right) 7.14\left(\mathrm{~d}, 2 \mathrm{H}, \mathrm{H}^{c}, J=7.8 \mathrm{~Hz}\right), 7.29$ $\left(\mathrm{d}, 4 \mathrm{H}, \mathrm{H}_{\mathrm{SIP}}{ }^{3}\right.$ and $\left.\mathrm{H}_{\mathrm{SIP}}{ }^{5}, J=7.8 \mathrm{~Hz}\right), 7.37\left(\mathrm{t}, 1 \mathrm{H}, \mathrm{H}^{d}\right), 7.48(\mathrm{t}$, $\left.2 \mathrm{H}, \mathrm{H}_{\text {SIP }}{ }^{4}\right) .{ }^{13} \mathrm{C}\left\{{ }^{1} \mathrm{H}\right\} \mathrm{NMR}\left(\mathrm{CDCl}_{3}, T=298 \mathrm{~K}, \mathrm{ppm}\right): \delta 18.3$ $\left(\mathrm{CH}_{3}{ }^{\mathrm{DIC}}\right), 23.9\left(\mathrm{CH}_{3}{ }^{\mathrm{SIP}}\right), 25.4\left(\mathrm{CH}_{3}{ }^{\mathrm{SIP}}\right), 28.8\left(\mathrm{HC}\left(\mathrm{CH}_{3}\right)_{2}\right), 54.7$ $\left(\mathrm{CH}_{2}\right), 124.5\left(\mathrm{C}^{a}\right), 124.6\left(\mathrm{C}_{\mathrm{SIP}}{ }^{3}\right.$ and $\left.\mathrm{C}_{\mathrm{SIP}}{ }^{5}\right), 128.6\left(\mathrm{C}^{c}\right), 130.3$ $\left(\mathrm{C}_{\mathrm{SIP}}{ }^{4}\right), 132.0\left(\mathrm{C}^{d}\right), 133.0\left(\mathrm{C}_{\mathrm{SIP}}{ }^{1}\right), 136.2\left(\mathrm{C}^{b}\right), 146.9\left(\mathrm{C}_{\mathrm{SIP}}{ }^{2}\right.$ and $\left.\mathrm{C}_{\text {SIP }}{ }^{6}\right), 199.4\left(\mathrm{NCN}_{\mathrm{SIP}}\right)$. IR (KBr pellet, $\left.\mathrm{cm}^{-1}\right): v 2963.4(\mathrm{CH})$, $2219.7(\mathrm{CN}), 1630.7,1586.7(\mathrm{CN}), 1495.4,1466.5(\mathrm{CC}), 1082.3$, 1057.4 $\left(\mathrm{BF}_{4}\right)$. Anal. Calcd for $\mathrm{C}_{36} \mathrm{H}_{48} \mathrm{AuBF}_{4} \mathrm{~N}_{3}: \mathrm{C}, 53.61 ; \mathrm{H}$, 6.00; N, 5.21. Found: C, 53.56; H, 6.10; N, 5.26.

$[\mathbf{A u}(\mathbf{I P r})(\mathbf{D I C})]\left(\mathbf{B F}_{4}\right)$. Yield: $91 \%$, white solid. ${ }^{1} \mathrm{H}$ NMR $\left(\mathrm{CDCl}_{3}, T=298 \mathrm{~K}, \mathrm{ppm}\right): \delta 1.30\left(\mathrm{~d}, 12 \mathrm{H}, \mathrm{CH}_{3}{ }^{\mathrm{IP}}, J=6.30\right.$ $\mathrm{Hz}), 1.32\left(\mathrm{~d}, 12 \mathrm{H}, \mathrm{CH}_{3}{ }^{\mathrm{P}}\right), 2.27\left(\mathrm{~s}, 6 \mathrm{H}, \mathrm{CH}_{3}{ }^{\mathrm{DIC}}\right), 2.54$ (septet, $\left.4 \mathrm{H},-\mathrm{CH}\left(\mathrm{CH}_{3}\right)_{2}\right), 7.16\left(\mathrm{~d}, 2 \mathrm{H}, \mathrm{H}^{c}, J=7.80 \mathrm{~Hz}\right), 7.36(\mathrm{t}, 1 \mathrm{H}$, $\left.\mathrm{H}^{\mathrm{d}}\right), 7.37\left(\mathrm{~d}, 4 \mathrm{H}, \mathrm{H}_{\mathrm{IP}}{ }^{3}\right.$ and $\left.\mathrm{H}_{\mathrm{IP}}{ }^{5}, J=7.8 \mathrm{~Hz}\right), 7.60\left(\mathrm{t}, 2 \mathrm{H}, \mathrm{H}_{\mathrm{IP}}{ }^{4}\right)$, $7.63(\mathrm{~s}, 2 \mathrm{H},-H \mathrm{C}=\mathrm{CH}-) .{ }^{13} \mathrm{C}\left\{{ }^{1} \mathrm{H}\right\} \mathrm{NMR}\left(\mathrm{CDCl}_{3}, T=298 \mathrm{~K}\right.$, ppm): $\delta 18.4\left(\mathrm{CH}_{3}{ }^{\mathrm{DIC}}\right), 23.9,24.8\left(\mathrm{CH}_{3}{ }^{\mathrm{IP}}\right), 28.8\left(\mathrm{HC}\left(\mathrm{CH}_{3}\right)_{2}\right)$, $124.4\left(\mathrm{C}_{\mathrm{IP}}{ }^{3}\right.$ and $\left.\mathrm{C}_{\mathrm{IP}}{ }^{5}\right), 125.9(-\mathrm{HC}=\mathrm{CH}-), 128.6\left(\mathrm{C}^{\mathrm{c}}\right), 131.2$ $\left(\mathrm{C}_{\mathrm{IP}}{ }^{4}\right), 131.9\left(\mathrm{C}^{d}\right), 132.9\left(\mathrm{C}_{\mathrm{IP}}{ }^{1}\right), 136.2\left(\mathrm{C}^{b}\right), 145.7\left(\mathrm{C}_{\mathrm{IP}}{ }^{2}\right.$ and $\left.\mathrm{C}_{\mathrm{IP}}{ }^{6}\right)$, $178.6\left(\mathrm{NCN}_{\mathrm{IP}}\right)$. IR (KBr pellet, $\left.\mathrm{cm}^{-1}\right)$ : $v 2965.10(\mathrm{CH}), 2212.8$ $(\mathrm{CN}), 1547.63(\mathrm{CN}), 1471.23(\mathrm{CC}), 1082.8,1037.2\left(\mathrm{BF}_{4}\right)$. Anal. Calcd for $\mathrm{C}_{36} \mathrm{H}_{46} \mathrm{AuBF}_{4} \mathrm{~N}_{3}$ : C, 53.74; H, 5.76; N, 5.22. Found: C, 53.81; H, 5.70; N, 5.25.

$\left[\mathrm{Au}(\mathrm{SIMes})\left\{\mathbf{C}(\mathbf{N H A r})\left(\mathbf{N C}_{\mathbf{5}} \mathbf{H}_{\mathbf{1 0}}\right)\right\}\right]\left(\mathbf{B F}_{\mathbf{4}}\right)$. A $0.021 \mathrm{~mL}$ portion $(0.208 \mathrm{mmol})$ of piperidine was added to a stirred solution of [Au(SIMes)(DIC)](BF $\mathrm{BF}_{4}(0.100 \mathrm{~g}, 0.139 \mathrm{mmol})$ in $10 \mathrm{~mL}$ of dichloromethane. After 15 min the solution was treated with activated charcoal and filtered through Celite and the solvent removed under reduced pressure. A 1:1 mixture of $\mathrm{Et}_{2} \mathrm{O}$ and $n$ hexane was added to the crude product, which was filtered off and washed with $n$-pentane $(3 \times 3 \mathrm{~mL})$. The resulting solid was dried under vacuum.

Yield: $94 \%$, white solid. ${ }^{1} \mathrm{H}$ NMR $\left(\mathrm{CDCl}_{3}, T=298 \mathrm{~K}\right.$, ppm): $\delta 1.26\left(\mathrm{bs}, 2 \mathrm{H}, \mathrm{H}_{\mathrm{pip}}{ }^{4}\right), 1.60\left(\mathrm{bs}, 4 \mathrm{H}, \mathrm{H}_{\mathrm{pip}}{ }^{3}\right.$ and $\left.\mathrm{H}_{\mathrm{pip}}{ }^{5}\right), 1.80(\mathrm{~s}, 6 \mathrm{H}$, $\left.\mathrm{CH}_{3}{ }^{\mathrm{Ar}}\right), 2.08\left(\mathrm{~s}, 12 \mathrm{H}, \mathrm{CH}_{3}{ }^{\mathrm{SIM}}\right), 2.35\left(\mathrm{~s}, 6 \mathrm{H}, \mathrm{CH}_{3}{ }^{\mathrm{SIM}}\right), 3.44(\mathrm{bt}$, $\left.2 \mathrm{H}, \mathrm{H}_{\text {pip }}{ }^{2}, J=5.3 \mathrm{~Hz}\right), 3.48\left(\mathrm{bt}, 2 \mathrm{H}, \mathrm{H}_{\text {pip }}{ }^{6}, J=5.3 \mathrm{~Hz}\right), 3.92$ $\left(\mathrm{s}, 4 \mathrm{H}, \mathrm{CH}_{2}\right), 6.80\left(\mathrm{~d}, 2 \mathrm{H}, \mathrm{H}^{c}, J=7.6 \mathrm{~Hz}\right), 6.92\left(\mathrm{~s}, 4 \mathrm{H}, \mathrm{H}_{\mathrm{SIM}}{ }^{3}\right.$ and $\left.\mathrm{H}_{\mathrm{SIM}}{ }^{5}\right), 7.00\left(\mathrm{t}, 1 \mathrm{H}, \mathrm{H}^{d}\right), 7.84(\mathrm{bs}, 1 \mathrm{H}, \mathrm{NH}) .{ }^{13} \mathrm{C}\left\{{ }^{1} \mathrm{H}\right\} \mathrm{NMR}$ $\left(\mathrm{CDCl}_{3}, T=298 \mathrm{~K}, \mathrm{ppm}\right): \delta 17.6\left(\mathrm{CH}_{3}{ }^{\mathrm{SIM}}\right), 18.1\left(\mathrm{CH}_{3}{ }^{\mathrm{Ar}}\right), 21.0$ $\left(\mathrm{CH}_{3}{ }^{\mathrm{SIM}}\right), 24.2,25.7\left(\mathrm{C}_{\text {pip }}{ }^{3}\right.$ and $\left.\mathrm{C}_{\text {pip }}{ }^{5}\right), 27.0\left(\mathrm{C}_{\text {pip }}{ }^{4}\right), 45.6\left(\mathrm{C}_{\text {pip }}{ }^{6}\right)$, $50.9\left(\mathrm{CH}_{2}\right), 56.4\left(\mathrm{C}_{\text {pip }}{ }^{2}\right), 127.5\left(\mathrm{C}^{d}\right), 127.7\left(\mathrm{C}^{c}\right), 129.4\left(\mathrm{C}_{\mathrm{SIM}^{3}}{ }^{2}\right.$ and $\left.\mathrm{C}_{\text {SIM }}{ }^{5}\right), 134.1\left(\mathrm{C}_{\text {SIM }}{ }^{4}\right), 135.4\left(\mathrm{C}_{\text {SIM }}{ }^{2}\right.$ and $\left.\mathrm{C}_{\text {SIM }}{ }^{6}\right), 136.4\left(\mathrm{C}^{a}\right), 138.0$ $\left(\mathrm{C}^{b}\right), 138.7$ ( $\left.\mathrm{C}_{\text {SIM }}^{1}\right), 207.4\left(\mathrm{NCN}_{\text {SIM }}\right), 201.2$ ( $\left.\mathrm{NCN}_{\text {ACYCLIC }}\right)$. IR (KBr pellet, $\left.\mathrm{cm}^{-1}\right): v 3310.62(\mathrm{NH}), 2941.7,2857.7(\mathrm{CH}), 1554.5$ (CN), $1506.6(\mathrm{CC}), 1082.5,1052.5\left(\mathrm{BF}_{4}\right)$. Anal. Calcd for $\mathrm{C}_{35} \mathrm{H}_{48^{-}}$ $\mathrm{AuBF}_{4} \mathrm{~N}_{4}$ : C, 51.99; H, 5.98; N, 6.93. Found: C, 52.05; H, 5.91; $\mathrm{N}, 6.87$.

The following complexes were prepared under conditions similar to those for $\left[\mathrm{Au}(\mathrm{SIMes})\left\{\mathrm{C}(\mathrm{NHAr})\left(\mathrm{NC}_{5} \mathrm{H}_{10}\right)\right\}\right]\left(\mathrm{BF}_{4}\right)$ using the appropriate $[\mathrm{Au}(\mathrm{NHC})(\mathrm{DIC})]\left(\mathrm{BF}_{4}\right)$ precursor.

[Au(IMes) $\left.\left\{\mathbf{C}(\mathbf{N H A r})\left(\mathbf{N C}_{\mathbf{5}} \mathbf{H}_{\mathbf{1 0}}\right)\right\}\right]\left(\mathbf{B F}_{\mathbf{4}}\right)$. Yield: $82.0 \%$, white solid. ${ }^{1} \mathrm{H}$ NMR $\left(\mathrm{CDCl}_{3}, T=298 \mathrm{~K}, \mathrm{ppm}\right): \delta 1.29(\mathrm{bs}, 2 \mathrm{H}$, $\left.\mathrm{H}_{\text {pip }}{ }^{4}\right), 1.60\left(\mathrm{bs}, 4 \mathrm{H}, \mathrm{H}_{\text {pip }}{ }^{3}\right.$ and $\left.\mathrm{H}_{\text {pip }}{ }^{5}\right), 1.86\left(\mathrm{~s}, 6 \mathrm{H}, \mathrm{CH}_{3}{ }^{\mathrm{Ar}}\right), 1.87$ $\left(\mathrm{s}, 12 \mathrm{H}, \mathrm{CH}_{3}{ }^{\mathrm{IM}}\right), 2.40\left(\mathrm{~s}, 6 \mathrm{H}, \mathrm{CH}_{3}{ }^{\mathrm{M}}\right), 3.45\left(\mathrm{bt}, 2 \mathrm{H}, \mathrm{H}_{\text {pip }}{ }^{2}, J=\right.$ $5.4 \mathrm{~Hz}), 3.54$ (bt, $\left.2 \mathrm{H}, \mathrm{H}_{\mathrm{pip}}{ }^{6}, J=5.4 \mathrm{~Hz}\right), 6.78\left(\mathrm{~d}, 2 \mathrm{H}, \mathrm{H}^{c}, J=\right.$ 7.50), 6.94-6.98 (m, 5H, ${ }^{d}, \mathrm{H}_{\mathrm{IM}}{ }^{3}$ and $\left.\mathrm{H}_{\mathrm{IM}}{ }^{5}\right), 7.07(\mathrm{~s}, 2 \mathrm{H}$, $-H \mathrm{C}=\mathrm{CH}-), 8.04(\mathrm{bs}, 1 \mathrm{H}, \mathrm{N} H) \cdot{ }^{13} \mathrm{C}\left\{{ }^{1} \mathrm{H}\right\} \mathrm{NMR}\left(\mathrm{CDCl}_{3}, T=\right.$ $298 \mathrm{~K}, \mathrm{ppm}): \delta 17.3\left(\mathrm{CH}_{3}{ }^{\mathrm{IM}}\right), 18.2\left(\mathrm{CH}_{3}{ }^{\mathrm{Ar}}\right), 21.1\left(\mathrm{CH}_{3}{ }^{\mathrm{IM}}\right), 24.2$, $25.7\left(\mathrm{C}_{\text {pip }}{ }^{3}\right.$ and $\left.\mathrm{C}_{\text {pip }}{ }^{5}\right), 27.0\left(\mathrm{C}_{\text {pip }}{ }^{4}\right), 45.8\left(\mathrm{C}_{\text {pip }}{ }^{6}\right), 56.4\left(\mathrm{C}_{\text {pip }}{ }^{2}\right)$, $122.7(-\mathrm{HC}=\mathrm{CH}-), 127.4\left(\mathrm{C}^{\mathrm{d}}\right), 127.6\left(\mathrm{C}^{c}\right), 129.2\left(\mathrm{C}_{\mathrm{IM}}{ }^{3}\right.$ and $\left.\mathrm{C}_{\mathrm{IM}}{ }^{5}\right), 134.1\left(\mathrm{C}_{\mathrm{IM}}{ }^{4}\right), 134.4\left(\mathrm{C}_{\mathrm{IM}}{ }^{2}\right.$ and $\left.\mathrm{C}_{\mathrm{IM}}{ }^{6}\right), 136.3\left(\mathrm{C}^{b}\right), 137.3$ $\left(\mathrm{C}^{a}\right), 139.6\left(\mathrm{C}_{\mathrm{IM}_{1}^{1}}\right), 185.9\left(\mathrm{NCN}_{\mathrm{IM}}\right), 201.2\left(\mathrm{NC} \mathrm{N}_{\text {ACYCLIC }}\right)$ IR (KBr pellet, $\left.\mathrm{cm}^{-1}\right): v 3319.4(\mathrm{NH}), 2947.20,2858.3(\mathrm{CH}), 1549.2$ $(\mathrm{CN}), 1488.22,1439.3(\mathrm{CC}), 1083.3,1034.9\left(\mathrm{BF}_{4}\right)$. Anal. Calcd for $\mathrm{C}_{35} \mathrm{H}_{46} \mathrm{AuBF}_{4} \mathrm{~N}_{4}$ : C, 52.12; H, 5.75; N, 6.95. Found: C, $52.01 ; \mathrm{H}, 5.69 ; \mathrm{N}, 6.89$.

$\left[\mathbf{A u}(\mathbf{S I P r})\left\{\mathbf{C}(\mathbf{N H A r})\left(\mathbf{N C}_{\mathbf{5}} \mathbf{H}_{\mathbf{1 0}}\right)\right\}\right]\left(\mathbf{B F}_{\mathbf{4}}\right)$. The product was recovered with pentane. Yield: $90 \%$, white solid. ${ }^{1} \mathrm{H} \mathrm{NMR}\left(\mathrm{CDCl}_{3}\right.$, $T=298 \mathrm{~K}, \mathrm{ppm}): \delta 1.09\left(\mathrm{bs}, 2 \mathrm{H}, \mathrm{H}_{\text {pip }}{ }^{4}\right), 1.21\left(\mathrm{~d}, 12 \mathrm{H}, \mathrm{CH}_{3}{ }^{\mathrm{SIP}}\right.$, 
$J=6.6 \mathrm{~Hz}$ ), $1.29\left(\mathrm{~d}, 12 \mathrm{H}, \mathrm{CH}_{3}{ }^{\mathrm{SIP}}\right), 1.53\left(\mathrm{bs}, 4 \mathrm{H}, \mathrm{H}_{\text {pip }}{ }^{3}\right.$ and $\mathrm{H}_{\text {pip }}{ }^{5}$ ), $1.84\left(\mathrm{~s}, 6 \mathrm{H}, \mathrm{CH}_{3}{ }^{\mathrm{Ar}}\right), 2.84-2.93\left(\mathrm{~m}, 6 \mathrm{H},-\mathrm{CH}\left(\mathrm{CH}_{3}\right)_{2}\right.$ and $\left.\mathrm{H}_{\text {pip }}{ }^{2}\right)$, 3.43 (bs, $\left.2 \mathrm{H}, \mathrm{H}_{\text {pip }}{ }^{6}\right), 4.02\left(\mathrm{~s}, 4 \mathrm{H}, \mathrm{H}_{2} \mathrm{C}-\mathrm{CH}_{2}\right), 6.60\left(\mathrm{~d}, 2 \mathrm{H}, \mathrm{H}_{5}^{c}, J=\right.$ $7.50 \mathrm{~Hz}), 6.76\left(\mathrm{t}, 1 \mathrm{H}, \mathrm{H}^{d}\right), 7.16\left(\mathrm{~d}, 4 \mathrm{H}, \mathrm{H}_{\mathrm{SIP}}{ }^{3}\right.$ and $\mathrm{H}_{\mathrm{SIP}}{ }^{5}, J=$ $7.5 \mathrm{~Hz}), 7.40\left(\mathrm{t}, 2 \mathrm{H}, \mathrm{H}_{\mathrm{SIP}}{ }^{4}\right), 7.78(\mathrm{bs}, 1 \mathrm{H}, \mathrm{NH}) .{ }^{13} \mathrm{C}\left\{{ }^{1} \mathrm{H}\right\} \mathrm{NMR}$ $\left(\mathrm{CDCl}_{3}, T=298 \mathrm{~K}, \mathrm{ppm}\right): \delta 18.3\left(\mathrm{CH}_{3}{ }^{\mathrm{Ar}}\right), 23.9,24.9\left(\mathrm{CH}_{3}{ }^{\mathrm{SIP}}\right)$, 24.0, $25.4\left(\mathrm{C}_{\text {pip }}{ }^{3}\right.$ and $\left.\mathrm{C}_{\text {pip }}{ }^{5}\right), 27.7\left(\mathrm{C}_{\text {pip }}{ }^{4}\right) 28.7\left(\mathrm{HC}^{3}\left(\mathrm{CH}_{3}\right)_{2}\right), 45.6$ $\left(\mathrm{C}_{\text {pip }}{ }^{6}\right), 53.7\left(\mathrm{H}_{2} \mathrm{C}-\mathrm{CH}_{2}\right) 55.2\left(\mathrm{C}_{\text {pip }}{ }^{2}\right), 124.4\left(\mathrm{C}_{\mathrm{IP}}{ }^{3}\right.$ and $\left.\mathrm{C}_{\mathrm{IP}}{ }^{5}\right), 127.8$ $\left(\mathrm{C}^{d}\right), 128.0\left(\mathrm{C}^{c}\right), 129.9\left(\mathrm{C}_{\mathrm{SIP}}{ }^{4}\right), 133.5\left(\mathrm{C}_{\mathrm{SIP}}{ }^{1}\right), 135.4\left(\mathrm{C}^{b}\right), 136.4\left(\mathrm{C}^{a}\right)$, 146.2 ( $\mathrm{C}_{\text {SIP }}{ }^{2}$ and $\left.\mathrm{C}_{\mathrm{SIP}}{ }^{6}\right), 207.9\left(\mathrm{NCN}_{\mathrm{SIP}}\right), 200.6\left(\mathrm{NCN} \mathrm{N}_{\mathrm{ACYCLIC}}\right)$. IR $\left(\mathrm{KBr}\right.$ pellet, $\left.\mathrm{cm}^{-1}\right): v$ 2957.7, $2862.8(\mathrm{CH}), 1551.7(\mathrm{CN}), 1490.7$, 1460.7 (CC), $1079.6\left(\mathrm{BF}_{4}\right)$. Anal. Calcd for $\mathrm{C}_{41} \mathrm{H}_{60} \mathrm{AuBF}_{4} \mathrm{~N}_{4}$ : C, $55, .16 ; \mathrm{H}, 6.77 ; \mathrm{N}, 6.28$. Found: C, 55,.21; H, 6.81; N, 6.35.

$\left[\mathbf{A u}(\mathbf{I P r})\left(\mathbf{C}(\mathbf{N H A r})\left\{\mathbf{N C}_{\mathbf{5}} \mathbf{H}_{\mathbf{1 0}}\right)\right\}\right]\left(\mathbf{B F}_{\mathbf{4}}\right)$. Yield: $90 \%$, white solid. ${ }^{1} \mathrm{H} \mathrm{NMR}\left(\mathrm{CDCl}_{3}, T=298 \mathrm{~K}, \mathrm{ppm}\right): \delta 1.14\left(\mathrm{~d}, 12 \mathrm{H}, \mathrm{CH}_{3}{ }^{\mathrm{IP}}, J=\right.$ $7.2 \mathrm{~Hz}), 1.17\left(\mathrm{~d}, 12 \mathrm{H}, \mathrm{CH}_{3}{ }^{\mathrm{IP}}\right), \mathrm{H}_{\text {pip }}{ }^{4}$ obscured by $\mathrm{CH}_{3}{ }^{\mathrm{IP}}$ signals, $1.57\left(\mathrm{bs}, 4 \mathrm{H}, \mathrm{H}_{\text {pip }}{ }^{3}\right.$ and $\left.\mathrm{H}_{\text {pip }}{ }^{5}\right), 1.87\left(\mathrm{~s}, 6 \mathrm{H}, \mathrm{CH}_{3}{ }^{\mathrm{Ar}}\right), 2.39$ (septet, $\left.4 \mathrm{H},-\mathrm{CH}\left(\mathrm{CH}_{3}\right)_{2}\right), 3.01\left(\mathrm{bt}, 2 \mathrm{H}, \mathrm{H}_{\mathrm{pip}}{ }^{2}, J=5.7 \mathrm{~Hz}\right), 3.48(\mathrm{bt}, 2 \mathrm{H}$, $\left.\mathrm{H}_{\text {pip }}{ }^{6}, J=5.7 \mathrm{~Hz}\right), 6.62\left(\mathrm{~d}, 2 \mathrm{H}, \mathrm{H}^{c}, J=7.30\right), 6.77\left(\mathrm{t}, 1 \mathrm{H}, \mathrm{H}^{d}\right)$, $7.19(\mathrm{~s}, 2 \mathrm{H},-H \mathrm{C}=\mathrm{C} H-), 7.23\left(\mathrm{~d}, 4 \mathrm{H}, \mathrm{H}_{\mathrm{IP}}{ }^{3}\right.$ and $\mathrm{H}_{\mathrm{IP}}{ }^{5}, J=8.0$ $\mathrm{Hz}), 7.51$ (t, 2H, $\left.\mathrm{H}_{\mathrm{IP}}{ }^{4}\right), 7.89$ (bs, $\left.1 \mathrm{H}, \mathrm{NH}\right) .{ }^{13} \mathrm{C}\left\{{ }^{1} \mathrm{H}\right\} \mathrm{NMR}(\mathrm{CD}-$ $\left.\mathrm{Cl}_{3}, T=298 \mathrm{~K}, \mathrm{ppm}\right): \delta 18.3\left(\mathrm{CH}_{3}{ }^{\mathrm{Ar}}\right), 23.8,24.3\left(\mathrm{CH}_{3}{ }^{\mathrm{IP}}\right), 24.1$, $25.1\left(\mathrm{C}_{\text {pip }}{ }^{3}\right.$ and $\left.\left.\mathrm{C}_{\text {pip }}{ }^{5}\right), 27.5\left(\mathrm{C}_{\text {pip }}{ }^{4}\right), 28.6(\mathrm{HC})\left(\mathrm{CH}_{3}\right)_{2}\right), 45.6$ $\left(\mathrm{C}_{\text {pip }}{ }^{6}\right), 55.4\left(\mathrm{C}_{\text {pip }}{ }^{2}\right), 123.9(-\mathrm{CH}=\mathrm{CH}-), 124.1\left(\mathrm{C}_{\mathrm{IP}}{ }^{3}\right.$ and $\left.\mathrm{C}_{\mathrm{IP}}{ }^{5}\right)$, $127.7\left(\mathrm{C}^{d}\right), 127.9\left(\mathrm{C}^{c}\right), 130.7\left(\mathrm{C}_{\mathrm{IP}}{ }^{4}\right), 133.4\left(\mathrm{C}_{\mathrm{IP}}{ }^{1}\right), 135.5\left(\mathrm{C}^{b}\right)$, $136.6\left(\mathrm{C}^{a}\right), 145.2\left(\mathrm{C}_{\mathrm{IP}}{ }^{2}\right.$ and $\left.\mathrm{C}_{\mathrm{IP}}{ }^{6}\right), 187.4\left(\mathrm{NCN}_{\mathrm{IP}}\right), 200.4$ $\left(\mathrm{NCN}_{\text {ACYCLIC }}\right)$. IR (KBr pellet, $\left.\mathrm{cm}^{-1}\right)$ : $v 3316.6(\mathrm{NH}), 2964.3$, $2862.5(\mathrm{CH}), 1549.2(\mathrm{CN}), 1471.4,1417.6(\mathrm{CC}), 1083.2,1034.4$ $\left(\mathrm{BF}_{4}\right)$. Anal. Calcd for $\mathrm{C}_{41} \mathrm{H}_{58} \mathrm{AuBF}_{4} \mathrm{~N}_{4}: \mathrm{C}, 55, .29 ; \mathrm{H}, 6.56 ; \mathrm{N}$, 6.29. Found: C, 55,.35; H, 6.48; N, 6.32 .

Supporting Information Available: Tables and CIF files giving crystallographic data related to the crystal structure determination of the complexes [Au(IMes)(DIC) $] \mathrm{BF}_{4}$ and [Au(IMes)$\left.\left\{\mathrm{C}\left(\mathrm{NHC}_{6} \mathrm{H}_{3}(\mathrm{Me})_{2}\right)\left(\mathrm{NC}_{5} \mathrm{H}_{10}\right)\right\}\right] \mathrm{BF}_{4}$ and figures giving selected regressions of kinetic data and bidimensional NMR spectra. This material is available free of charge via the Internet at http:// pubs.acs.org. 